\title{
Municipal Solid Waste Management: A Review of Waste to Energy (WtE) Approaches
}

\begin{abstract}
Chhotu Ram, ${ }^{\mathrm{a}}$ Amit Kumar, ${ }^{\mathrm{b}, *}$ and Pushpa Rani ${ }^{\mathrm{c}}$
Global municipal solid waste (MSW) generation will increase to 2.2 billion tons per year by 2025 as per the World Bank projection. Improper waste management often leads to environmental degradation (i.e. water, air and soil pollution), transmission of diseases, and the release of greenhouse gases emissions, which contributes to climate change. To combat these problems, several countries are following the waste to energy (WtE) approach, which significantly reduces the volume of waste and generates renewable energy. Thus, the present study focuses on the municipal solid waste generation, composition, and waste to energy conversion technologies. Thermal conversion processes including incineration, pyrolysis, and gasification for heat, bio-oil, and syngas generation are already well established and are being employed in several countries. Currently, researchers are trying to improve the efficiency of biochemical methods such as anaerobic digestion, microbial fermentation, and microbial fuel cells for biogas, biohydrogen, and bioelectricity generation from MSW. This review explains the recent focus on microbial fermentation and microbial fuel cells for biofuels and bioelectricity production. Development of these technologies can lead to suitable ecofriendly approaches for the future. WtE technologies are important components of circular economy that will assist to achieve the demand of clean energy in future.
\end{abstract}

Keywords: Municipal solid waste; Waste to energy; Biochemical conversion; Anaerobic digestion; Thermal conversion

Contact information: a: Department of Chemical Engineering, College of Engineering and Technology, Adigrat University, Adigrat, Ethiopia; b: Department of Biotechnology, College of Natural and Computational Sciences, Debre Markos University, Ethiopia; c: Department of Environmental Science \& Engineering, Guru Jambheshwar University of Science and Technology, Hisar, Haryana, India;

* Corresponding author: baliyaniitr@gmail.com

\section{INTRODUCTION}

The world is experiencing a rapidly growing population and rising public living standard, which leads to increases in the generation of municipal solid waste (MSW) and consumption of energy and goods. These activities result in changes in land use, deforestation, intensified agricultural practices, industrialization, and energy use from fossil fuels. All of these practices along with the MSW generation lead to ever-growing concentrations of greenhouse gases (GHG) in the environment and higher risk to public health by unscientific disposal (Palacio 2019). MSW can be defined as non-hazardous, biodegradable/non-biodegradable, carbonaceous/non-carbonaceous, and reusable or unusable solid waste that is generated from households, offices, trade, garden, yard, and street (Ngusale et al. 2017; Abbasi 2018). MSW in the developing world is facing significant management and disposal problems. MSW management problems are more 
prominent in the middle- and low- income countries due to the fast growing population and urbanization (Alam and Ahmade 2013; Damtew and Desta 2015).

Previous work correlates the increase in solid waste generation rate with the increase in population, technological development, and changes in the public lifestyle (Ali 2009; Monavari et al. 2012; Leone et al. 2013). The solid waste management problems are more acute in developing countries than the developed countries (Zerbock 2003; World Bank 2012). Currently, the global population is reaching around 7.1 billion, and it generates around 1300 million tonnes of solid waste per year. For instance, the MSW is estimated to be around $1.2 \mathrm{~kg}$ per capita per day, which is mostly generated from the urban parts of the major cities. The waste amount is expected to reach up to 2200 million tonnes per year by the year 2025 (World Bank 2012). Hence, proper characterization and management of MSW are the need of the hour. Improper and inefficient solid waste management lead to GHGs emission, odors problems, and high risk to public health. It has been predicted that emission of GHGs from waste management in developing countries will increase exponentially (Friedrich and Trois 2011). Further, researchers (Memon 2010; Rotich et al. 2006) investigated that only 20 to $50 \%$ of municipalities in developing countries provide funds for solid waste management, which covers less than $50 \%$ of the total population. Therefore, solid waste management has become a hot issue due to environmental risks and challenges, which further has prompted researchers to consider MSW as a resource to be managed in a sustainable manner. Therefore, around the world to ensure sustainable MSW management, options such as mainly recycling, landfill with gas recovery, thermal, and biochemical conversion methods are being considered (Shekdar 2009). Recently, waste treatment processes generating energy from MSW in the form of heat, electricity, or transport fuels have received special attention and considered as waste to energy (WtE) options. WtE technology includes mainly pyrolysis, gasification, combustion, anaerobic digestion, biohydrogen production, and landfill gas recovery (Fig. 1). Among these, thermochemical conversion, anaerobic digestion, and landfilling with energy recovery options are based upon the theme of the energy recovery option in the MSW management hierarchy (Lu et al. 2006).

Previous estimation related to $\mathrm{WtE}$ showed that by 2025, 2.3 billion tons of solid waste will be generated annually, which will have huge potential effects on power generation (Islam 2016). Thus, the waste to energy approach is a promising energy alternative option for the future because of having potential to fulfill $10 \%$ of total global electricity demand (World Energy Council 2013). Another report suggests the utilization of $\mathrm{WtE}$ technology for the treatment of approximately 261 million tons per year of MSW by 2022 , which has potential to generate around 283 terawatt (TWh) hours of heat and electricity (World Energy Council 2013). The two most common strategies of WtE techniques are solid waste incineration and landfill gas recovery (LFG) systems (Tan et al. 2014), but the most suitable option from a financial perspective in the future energy system is mixed MSW incineration (Marie and Peter 2011). Some countries such as Denmark and Sweden already have had well-established energy generation systems based on incineration for more than a century. The data showed that waste incineration system produce $4.8 \%$ of the total electricity consumption and $13.7 \%$ of the total domestic heat consumption in Denmark (Kleis and Dalagar 2007). WtE technologies have received much attention due to significant waste volume reduction along with the renewable energy production to meet the present as well as the future energy demands. Therefore, the authors have planned a systematic and in depth study for solid waste generation, composition and sustainable MSW management using biochemical and thermal energy conversions approaches. 
Further, the present study can be helpful in the conservation and preservation of natural resources, environment, and public health, which further contribute to the general goals of sustainability.

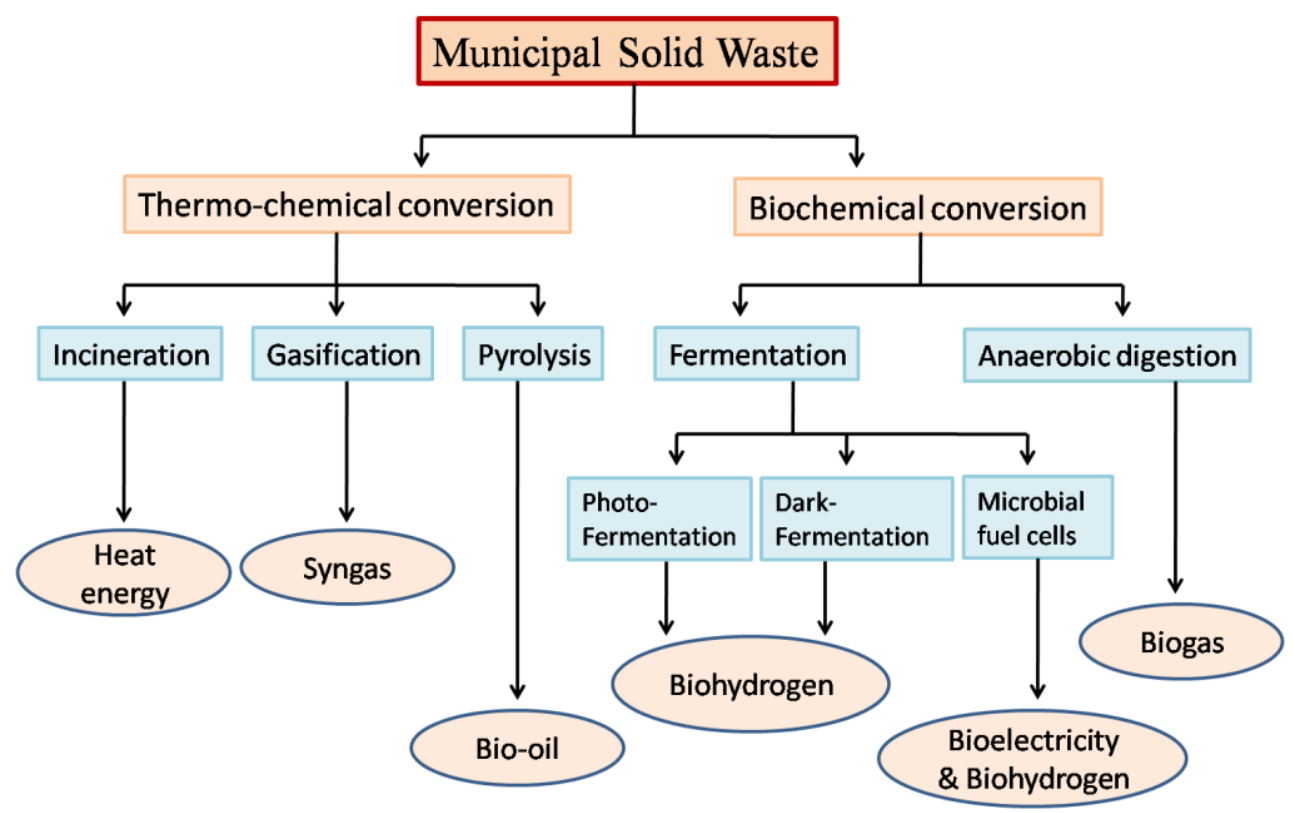

Fig. 1. Waste to energy technologies

\section{MSW Generation: Current Status and Future Prediction}

Municipal solid waste generation in term of quantity and future forecast is of utmost importance for the planning of waste management systems. Various reports have shown that increases in the quantity of waste generation worldwide have resulted due to the rise in population, urbanization, living standard, and industrialization in and around the town. Rapid industrialization is also responsible for people's migration from rural to urban areas for livelihood (Karak et al. 2012; Dev and Siddharth 2020). Thus, every individual is affected by the solid waste generation directly or indirectly. However, few authors have suggested any optimistic perspective regarding the increasing volumes of solid waste as being anything other than a problem. Further, a higher amount of MSW provides free resources and employment opportunities, especially for the poor and the marginalized people (Singh et al. 2011; Angelo 2014).

According to the United Nations' recent report (2019), the global population will continue to grow from an estimated 7.7 billion by year 2019 to around 8.5 billion in 2030 and 9.7 billion in 2050 (United Nations 2019). Thus, the increasing population will also increase the municipal solid waste generation worldwide in the future. A previous study in the United States by the Environmental Protection Agency showed the MSW generation from 1960 to 2012. It was found that total MSW generation increased from 88,120 tons to 250,890 tons from 1960 to 2012 (USEPA 2014). Table 1 presents an estimation of the municipal solid waste generated by various countries in 2017. In a similar manner, in another study, the author worked out the global population and MSW generation share by the major waste producing countries (Wang 2019). As of this time, the United States accounted for $4.4 \%$ of the global population but produced $11.65 \%$ of the global MSW. Thus, Table 2 provides a clear indication of global population and MSW share by the different countries. 
Table 1. MSW Generation in Different Countries (adapted from United Nations 2019)

\begin{tabular}{|c|l|c|}
\hline S. No. & \multicolumn{1}{|c|}{ Country } & $\begin{array}{c}\text { Waste generation ( million } \\
\text { metric tons per year) }\end{array}$ \\
\hline 1. & Unites States & 258 \\
\hline 2. & China & 220.4 \\
\hline 3. & India & 168.4 \\
\hline 4. & Brazil & 79.89 \\
\hline 5. & Indonesia & 65.2 \\
\hline 6. & Russia & 60 \\
\hline 7. & Mexico & 53.1 \\
\hline 8. & Germany & 51.05 \\
\hline 9. & Japan & 43.98 \\
\hline 10. & France & 33.4 \\
\hline 11. & United Kingdom & 31.57 \\
\hline 12. & Turkey & 31.28 \\
\hline 13. & Pakistan & 30.76 \\
\hline 14. & Nigeria & 27.61 \\
\hline 15. & Canada & 25.1 \\
\hline 16. & South Africa & 18.46 \\
\hline 17. & Korea & 18.22 \\
\hline 18. & Argentina & 17.91 \\
\hline 19. & Saudi Arabia & 16.13 \\
\hline 20. & Australia & 13.35 \\
\hline & & \\
\hline
\end{tabular}

Research from China reflects that the total amount of solid waste generation has risen for almost all 651 cities from 2007 to 2016. China shows an annual per capita municipal solid waste generation (MSWG) that is greatly varying, which indicates that the rising trend of MSWG is full of diversity (Pan et al. 2019). The developed countries and developing countries have differences in their lifestyle and development scenarios, which ultimately are responsible for the quantity of solid waste generation and its characteristics. The developed countries typically generate an average of 522.0 to $759.2 \mathrm{~kg}$ per capita per year (kcy), which is generally higher than the 109.5 to $525.6 \mathrm{kcy}$ typically by developing countries (Karak et al. 2012).

A study from 15 countries of the European Union (EU-15) indicated that the average MSW generation increased in the EU-15 by $4.6 \%$ from 540 to $565 \mathrm{kcy}$ from 1998 to 2008. Among theEU-15 in 2008, a considerably higher amount of solid waste generation, i.e. $802 \mathrm{kcy}$, was observed (Eurostat 2009). However, Greece was observed to generate the lowest rate of MSW, i.e. $453 \mathrm{kcy}$, among the EU-15 countries in the year 2008 (Erkut et al. 2008; Eurostat 2009). China, the world's most populated country, delivered a total MSW of approximately 203.62 million tonnes in 2016, an increase of $33.83 \%$ compared to 10 years ago (Yearbook 2017). 
Table 2. Global Populations and MSW Generation in Various Countries (adapted from Wang 2019)

\begin{tabular}{|c|l|c|c|}
\hline S. No. & Country & $\begin{array}{c}\text { Share of global } \\
\text { population (\%) }\end{array}$ & $\begin{array}{c}\text { Share of global MSW } \\
(\%)\end{array}$ \\
\hline 1. & China & 18.75 & 15.55 \\
\hline 2. & India & 18.05 & 11.95 \\
\hline 3. & Unites States & 4.4 & 11.65 \\
\hline 4. & Indonesia & 3.55 & 3.30 \\
\hline 5. & Brazil & 2.8 & 3.85 \\
\hline 6. & Russia & 1.95 & 2.4 \\
\hline 7. & Japan & 1.70 & 2.15 \\
\hline 8. & Germany & 1.15 & 1.95 \\
\hline 9. & United Kingdom & 0.90 & 1.50 \\
\hline 10. & South Africa & 0.75 & 0.70 \\
\hline 11. & Canada & 0.45 & 1.40 \\
\hline 12. & Saudi Arabia & 0.45 & 0.75 \\
\hline 13. & Australia & 0.35 & 0.75 \\
\hline
\end{tabular}

The status of worldwide solid waste generation is around 2.01 billion tonnes as of 2016 and amounting to a footprint of $0.74 \mathrm{~kg}$ per capita per day. Furthermore, with fast growing populations and the urbanization sector, the annual solid waste generation rate is expected to increase to about 3.40 billion tonnes in 2050 which is $70 \%$ higher compared to 2016 levels (World Bank 2019). The World Bank's initiative is ambitious to combat the waste management problems in all the six regions since 2000. For this purpose, the World Bank spent over $\$ 4.7$ billion for more than the 340 solid waste management programs. MSW generation is predicted to exceed the rate of urbanization in 2025, and in the coming decades the total MSW generation rate in developing countries will also increase rapidly (Fazeli et al. 2016). Thus, it is of utmost importance to be able to predict the generation of solid waste in order to select appropriate waste treatment technology and to plan for the needed waste distribution disposal facilities. A recent study from China established the usefulness of a hybrid model to forecast MSW generation. This approach involves multivariate factors such as total urban population, retail sales aspect of social consumer goods, tourism, per capita consumption expenditure of urban areas, and college graduation. The developed hybrid model has a mean absolute percentage error of only $2.59 \%$ and yields higher accuracy (Zhang et al. 2019). In another study, researchers developed four models to forecast the amount of MSWG for cities overall, small cities (SC), medium cities (MC), and large cities (LC). Thus, the overall models have a descriptive capacity of $96 \%$, while three other models have better descriptive capacity with $84.2 \%, 92.6 \%$, and $95.4 \%$ for SC, $\mathrm{MC}$, and LC, respectively. Thus, these kinds of studies are useful for urban planners and environmentalists to improve SW generation and management through the different socioeconomic characteristics with a specific model for various cities based on their size (Pan et al. 2019). The findings discussed in this brief overview support a general view that MSW management is a key area for environmental preservation in the present and future scenario. 


\section{Characteristics and MSW Management Strategies}

The main components of MSW generated around the world are paper and paperboard, kitchen waste, yard waste, metals and ceramics, glass, plastic, wood, textiles, rubber, leather, batteries, and paint containers (Nanda and Berruti 2020; Cudjoe et al. 2021). This review has focused on energy generation from MSW using different WtE technologies. The utilization and valorization of wastewater 'sludge' has not been considered for this review. Information on the types and amounts of waste is important in assessing the waste composition in the landfills. The prior information can help to properly monitor the effectiveness of the program and to divert the recyclable and compostable materials from landfills. MSW characterization studies are used to assist in the planning, policy development, and infrastructure sizing decisions for various facets of an integrated and sustainable waste management program. For many municipalities and geographical locations, the waste characterization goals are influenced by multiple factors, e.g. program objectives and available funds. Hence, the design and implementation of a sound characterization methodology for solid waste management (SWM) will ultimately dictate the resulting accuracy and details (Staley and Barlaz 2009). Sometimes making comparisons between various reports becomes challenging due to the methodology available, which can lead to inconsistencies in solid waste composition and waste quantities. There are basically two most widely used methods for the waste characterization. These are the material flow method and site-sampling via sorting and weighing refuse by category (Martin et al. 1995). The sampling and sorting method is the more prevalent of the two. A standard method for determining waste composition by sorting has been published and is used widely ASTM D 5231-92 (ASTM 1999). The American Society for Testing and Materials (ASTM) method notes that:

(1) The number of samples is to be based upon statistical criteria.

(2) The sampling site should be randomized and performed over a 5 to 7-day period.

(3) After sample collection to get proper weight, four times weighing is required for subsamples after sorting. Hence, the techniques provide an abbreviated list of waste constituents categories and their definitions.

Thus, with this brief background, Table 3 represents the details of physical composition of MSW generated in different countries and cities. It indicates that MSW composition differs with the topographical site, standard of living, life advancement, and the population of the city, etc. (Zuberi and Ali 2015). Low and medium-income countries mostly generate higher proportions of organics or biodegradable MSW, which could be used for the composting, gasification, or landfilling for final disposal. However, the MSW composition such as density, size, and moisture content play a crucial role. Hence, lesser size organic waste tends to decompose at a faster rate (Beyene et al. 2018). Waste having higher density is considered as eco-friendly waste and will undertake a faster rate of decomposition as compared to lesser density waste, and it constitutes the more combustible waste materials (paper, cardboard, plastics). Moisture content of waste is an important parameter; generally, a higher moisture content of waste is more suitable for anaerobic treatment, landfill gas, and bio-digester gas (Zuberi and Ali 2015). It can be seen as an example of organic fraction of MSW due to mainly large content of food waste, kitchen waste, and leftovers from residences, restaurants, cafeterias, factory lunch-rooms, and markets, etc., and have high moisture content and high biodegradability proportion (Beylot et al. 2013; Alibardi and Cossu 2015) 
One study showed a correlation between the quality of waste generated depending upon the climatic conditions, food patterns, etc., in various locations (Singh and Leena 2020). It is very important to find the suitable waste characteristics in order to find suitable and feasible waste to energy conversion technology. Table 4 gives the details about the various chemical composition of MSW generated and checked by various researchers in different countries.

A current issue is how to deal with the increasing quantity of SW and further associated challenges for effective and sustainable waste management. The open dumping of SW causes serious environmental issues, including the uncontrolled release of greenhouse gases, which can render a waste management system un-sustainable (Matsakas et al. 2017). For effective waste management, most of the municipal corporation services require an integrated system that is efficient, sustainable, and socially supported. However, an effective waste management system requires appropriate financial resources, infrastructure, and technology (Kazuva and Zhang 2019).

There are several methods and techniques available to manage the solid waste generated from society. Policy makers are also thinking to promote the recycling of MSW and the conversion of waste to energy and valuable chemicals in various countries. These conversions can be performed using either biological or thermochemical processes (Matsakas et al. 2017). In addition, energy can be recovered from the waste in the form of refuse-derived fuel, bio-oil, char, compost, and biogas, etc. (Singh and Leena 2020). Various other conventional methods such as composting, landfilling, and incineration that are being used for the treatment and management of waste have some negative impacts. In general, problems in developing countries tend to be more severe than the developed countries because of unscientific waste management practices. 
Table 3. Physical Composition of MSW Generated from Different Countries

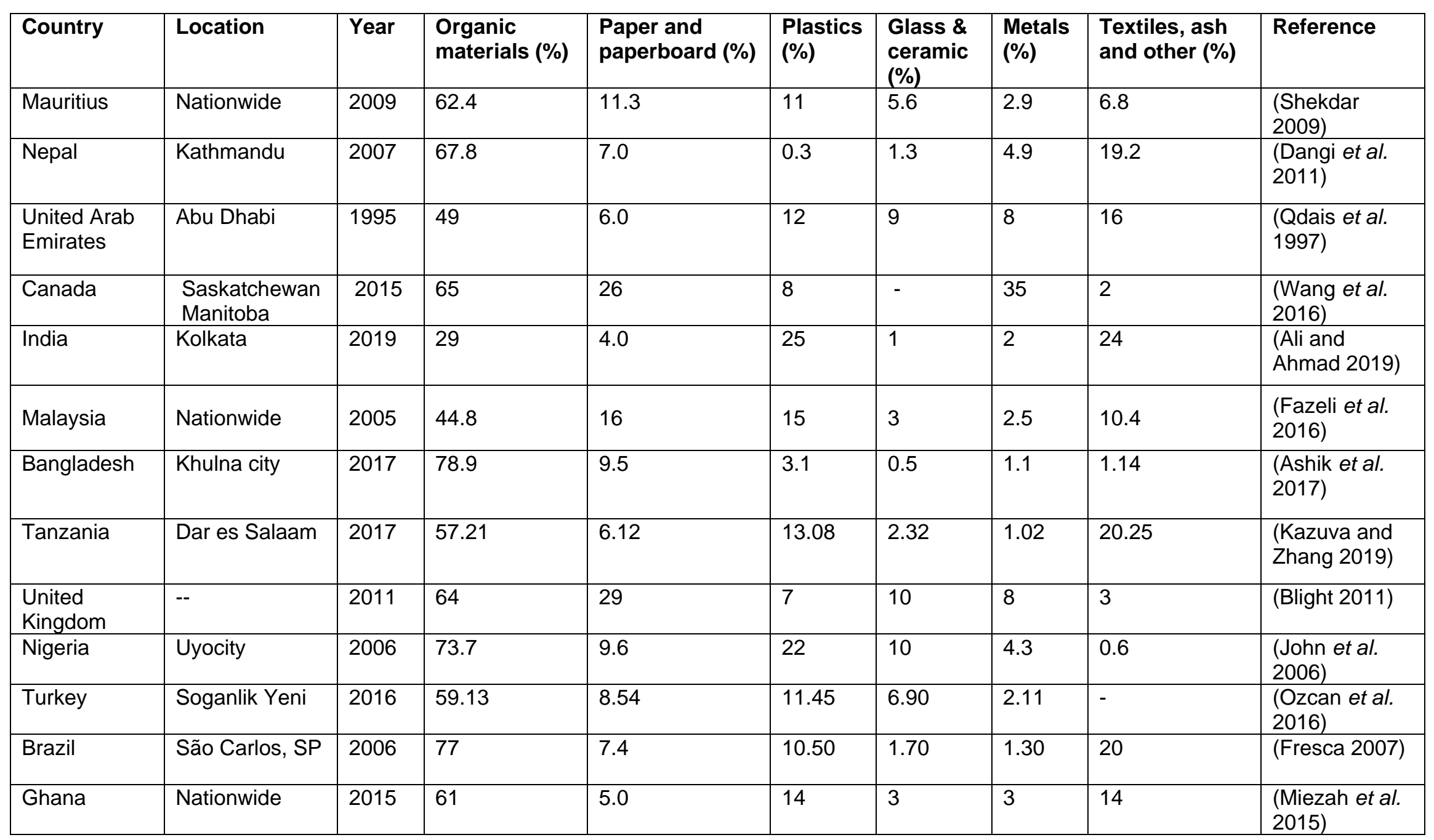


Table 4. Chemical Composition of MSW Generated in Different Countries

\begin{tabular}{|c|c|c|c|c|c|c|c|c|c|c|}
\hline Country & $\begin{array}{l}\text { Moisture } \\
\text { content }\end{array}$ & $\begin{array}{l}\text { Volatile } \\
\text { matter }\end{array}$ & $\begin{array}{l}\text { Organic } \\
\text { carbon }\end{array}$ & $\begin{array}{l}\text { Organic } \\
\text { nitrogen }\end{array}$ & C & $\mathbf{H}$ & 0 & $\mathbf{S}$ & Ash & Reference \\
\hline India & 30.76 & - & 30.46 & 1.04 & - & - & - & - & 46.7 & (Katiyar et al. 2013) \\
\hline Ireland & 16.36 & - & 38.7 & 1.2 & - & 7.2 & 48.1 & 0.2 & 4.6 & (Yusuff et al. 2014) \\
\hline South Africa & 63.47 & - & 45.03 & 1.98 & - & - & 41.2 & 0 & 5.56 & (Ayeleru et al. 2016) \\
\hline Korea & 2.30 & 87 & 40.3 & 0.2 & 40.3 & 5.6 & 53 & - & - & (Kim et al. 2012) \\
\hline Pakistan & 3.30 & 79.7 & - & - & 63.6 & 8.19 & 27 & 0.1 & 9.1 & (Azam et al. 2020) \\
\hline Mexico & 65 & - & $\begin{array}{l}50.4- \\
75.5\end{array}$ & - & 61.2 & 15.4 & 7.45 & 0.02 & 13 & (Moreno et al. 2013) \\
\hline Australia & $\begin{array}{l}28.7- \\
46.0\end{array}$ & $\begin{array}{l}65.5- \\
71.1\end{array}$ & - & - & $\begin{array}{l}43.9- \\
47.5\end{array}$ & $\begin{array}{l}5.2- \\
5.4\end{array}$ & $\begin{array}{l}35.31- \\
38\end{array}$ & $\begin{array}{l}0.12- \\
0.14\end{array}$ & $\begin{array}{l}7.9- \\
14.2\end{array}$ & (Hla and Roberts 2015) \\
\hline Kazakhstan & 2.6 & 72 & - & - & 47.9 & 5.9 & 43.6 & 0.2 & 11.2 & (Abylkhani et al. 2019) \\
\hline Zimbabwe & $\begin{array}{l}30.9- \\
36\end{array}$ & $\begin{array}{l}79.2- \\
84\end{array}$ & - & - & $\begin{array}{l}44.6- \\
47.9\end{array}$ & $\begin{array}{l}4.8- \\
5.1\end{array}$ & $\begin{array}{l}30.8- \\
37.3\end{array}$ & $\begin{array}{l}0.8- \\
0.8\end{array}$ & $\begin{array}{l}8.3- \\
12.5\end{array}$ & (Makarichi et al. 2019) \\
\hline Bangladesh & $\begin{array}{c}0- \\
74.86\end{array}$ & - & $\begin{array}{l}24.3- \\
55\end{array}$ & - & - & $\begin{array}{l}0.1- \\
22.8\end{array}$ & $0.4-44$ & $\begin{array}{l}0.2- \\
90.5\end{array}$ & $0.46-98.9$ & (Islam 2016) \\
\hline Malaysia & 14.6 & 69.35 & - & - & - & - & - & - & 7.05 & (Khamis et al. 2019) \\
\hline
\end{tabular}


Literature also documents the same findings from the developing world and challenges associated with the waste management. Thus, waste to energy (WtE) is a very attractive option, which has potential advantages in the volume reduction and power generation as by-product. The developing world is more focusing towards the waste to energy (WtE) production due to the continuous increasing the price of non-renewable energy (Chakraborty et al. 2013; Korai et al. 2016). The role of calorific value of waste is important in assessing the thermochemical treatment technologies. An input feed with a sufficiently high calorific value is required to obtain suitable process efficiency. It has been suggested to use refuse-derived fuel processed from raw MSW for WtE systems (Klein 2002). One study from Nigeria cites the average calorific value of waste samples tested as $20,199 \mathrm{~kJ} / \mathrm{kg}$, which was found to be higher than required for running a waste to energy plant (Olisa and Ajoko 2018). Another work investigates the lowest and highest calorific values i.e. 14,000 and 45,000 kJ/kg for wood and plastic wastes from Kandy city of Sri Lanka. Kandy municipality has the potential to generate $69.3 \mathrm{GWh} / \mathrm{yr}$ power, and it could replace $15 \%$ of the annual energy requirement of the city (Menikpura et al. 2007). However, various researchers have worked on the estimation of solid waste calorific value, as well as their application for energy production (Beyene et al. 2018; Siddiqi et al. 2019). Thus, the $\mathrm{WtE}$ conversion technologies, i.e. thermal and biochemical conversion systems have been considered for the up-to-date reviews in the present study.

\section{Thermal Conversion Processes}

MSW as waste materials can be converted into the usable heat electricity or fuel through a variety of processes including combustion, gasification, and pyrolization. These processes involve the high temperature waste treatment method and are collectively known as thermal treatment. Figure 2 describes the waste treatment methods with their conditions in practice.

\section{Incineration}

It will be a major challenge to rapidly grow MSW, especially in developing countries, to meet the expected present and future needs. Incineration technology is regarded as an effective and sound technology for MSW management (Fig. 3). However, there are still various challenges associated with incineration. These include characterization, valorization, heavy metal removal from ash, and air emissions such as dioxin emissions (Wong et al. 2020). Further, incineration has advantages due to reduction of the landfill requirements and energy recovery potential in the solid waste materials being burned (Chandler et al. 1997). One report suggests the reduction of solid mass of the original waste materials by 80 to $85 \%$ and volume reduction achieved by 95 to $96 \%$, depending upon the properties of the waste (Riber 2006). This supports the earlier statement that solid waste combustion does not completely eliminate landfilling; thereby, some percentage of burnt ash needs to be securely landfilled. Furthermore, to protect our environment from the ecological risk due to heavy metals containing fly and bottom ash, strict environmental regulation and regular monitoring is required to reduce air, water, and soil pollution. Research and development activities are necessary for resource recovery and ash stabilization in the sustainable manner to reduce the environmental risks.

The first incinerators were used in the United Kingdom in 1874 in Nottingham, followed by New York City, USA in 1885. Around the world, solid waste combustion is more popular in many countries such as Netherlands, Singapore, and Japan due to the scarcity of land. Sweden and Denmark have been the leaders in the use of energy generated 
from incineration for more than a century with joint heat and power systems (Kleis and Dalagar 2007). Denmark reported the utilization of waste to produce around $4.8 \%$ of the electricity consumption and $13.7 \%$ of the total heat consumption in the country (Danish Energy Statistics 2005). Sweden imports approximately 2,700,000 tons of waste per year (2014) to supply waste to energy facilities, and $50 \%$ of its own waste is burnt in the same facilities (Swedish Institute 2015). A similar scenario has been played out in many other European countries, using heat and power generated from waste burning. The Energy Information Administration (USA) gives a detailed account on the waste to energy from municipal solid waste. It was observed that total MSW generated in the USA in 2017 was about 268 million tons, and $12.7 \%$ was estimated to be burned as part of waste to energy incineration. The USA is reported to have 68 such power plants, which generate $c a .14$ billion kilowatt hours of power by burning of 29.5 million tons of MSW (US EIA 2019).
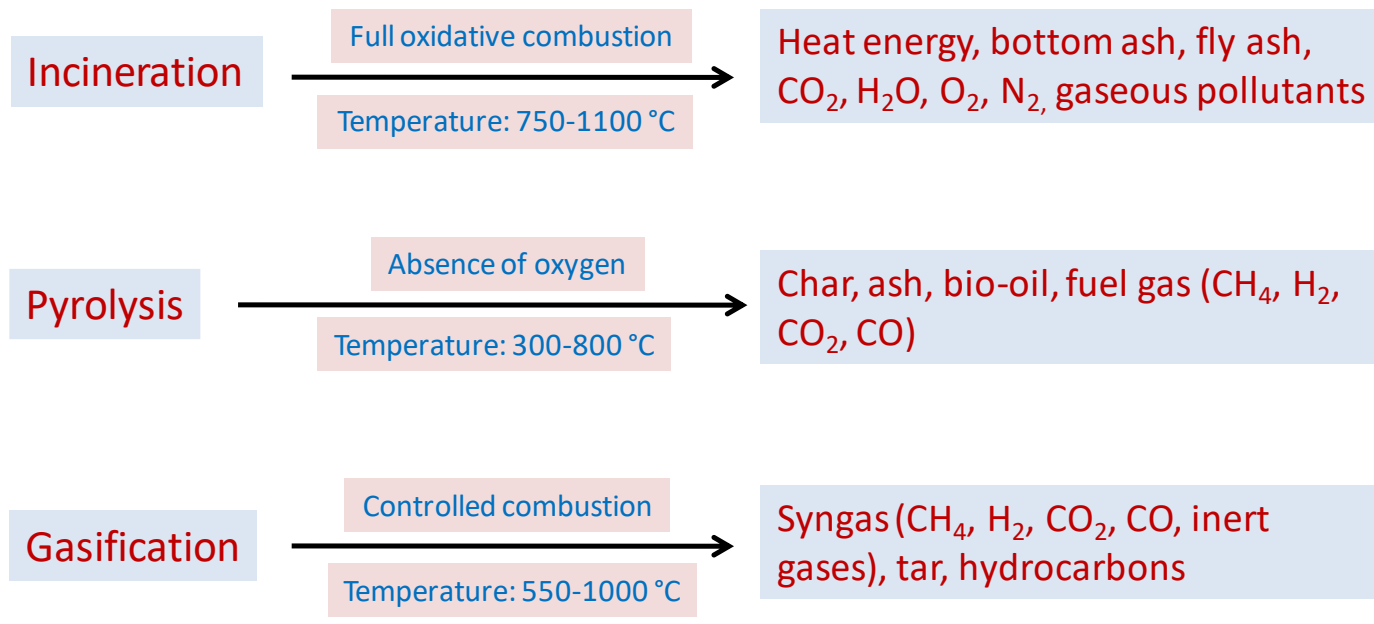

Fig. 2. Process conditions and products of thermal conversion processes

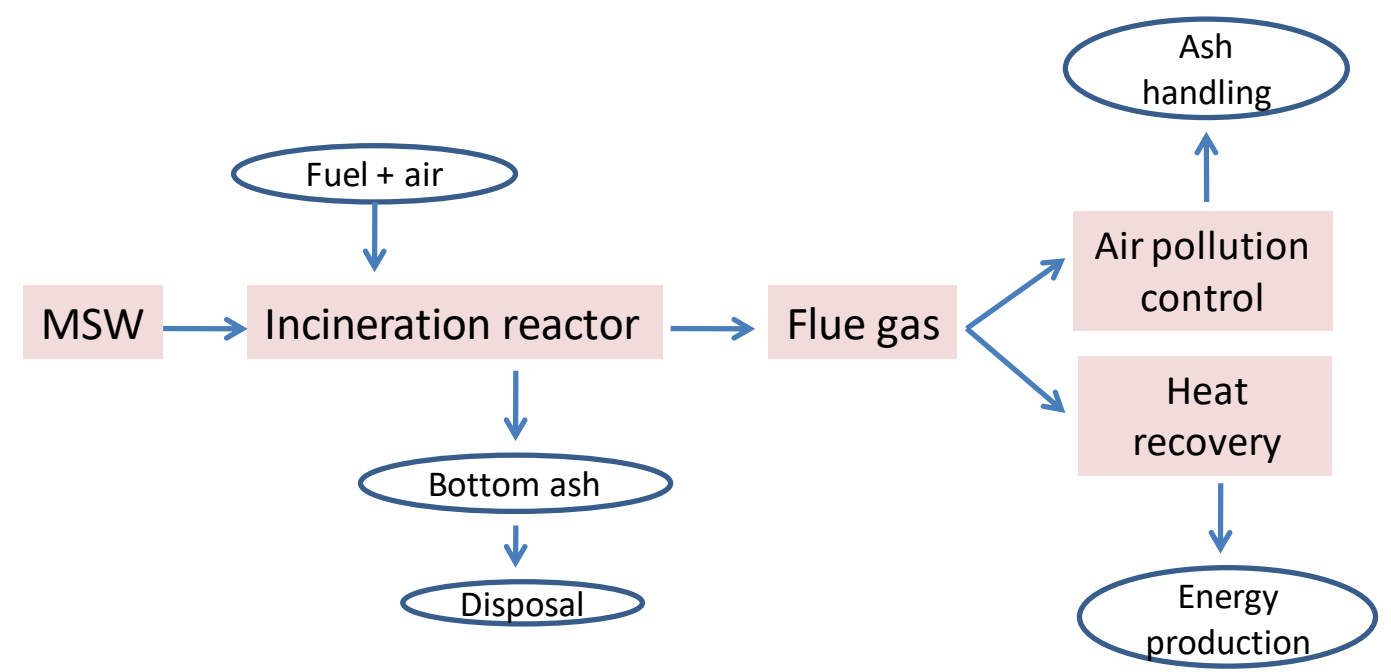

Fig. 3. Process diagram for incineration, modified from (Uz Zaman 2009) 
Study of MSW composition in China has revealed problems due to relatively low calorific value (LCV) and high moisture content compared to fossil fuels (Zhang and Ma 2006). Thus, a novel method has been proposed in which the incineration of MSW is coupled with a biochemical method. Accordingly, leachate and low heat value food waste in MSW are treated with anaerobic digestion method and anaerobic digested residue is dried and mixed with high LCV combustible components in MSW. Results indicated that fossil fuel is saved, incinerator efficiency is satisfied, and flexibility is improved. This novel technology can improve the total energy utilization efficiency of MSW power plant (Zhang and Ma 2006). Another work proposed the designing of a control system to ensure good combustion characteristics for MSW. The incineration facility included a grate system, as well as primary and secondary air systems, which were shown to be an improved strategy, offering significant economic and environmental advantages (Qin et al. 2008). The author highlighted that incineration technology for MSW has overtaken the landfilling in China.

A major challenge is associated with the heavy metals management of incinerated ash. In this connection, mass flow modeling observations of MSW in China estimated metals contents in ash of 3.0, 109, 101, 877, 34, 241, 21, and $1.7 \mathrm{mg} / \mathrm{kg}$ for i.e. $\mathrm{Cd}, \mathrm{Pb}, \mathrm{Cr}$, $\mathrm{Zn}, \mathrm{Ni}, \mathrm{Cu}, \mathrm{As}$, and $\mathrm{Hg}$, respectively (Table 5). The grate furnace combustor (GFC) technology released more heavy metals during MSW burning in comparison with a circulating fluidized bed combuster (CFBC) (Wang et al. 2019). Thus, to mitigate adverse environmental effects, researchers (Quina et al. 2018) focused on the technological management of air pollution control residues and the fly ash, which is continuously increasing in the MSW incineration, especially in developing countries. The waste comes under the hazardous category and presently is disposed of by landfilling and deep ground burial. Literature suggests the recovery of secondary materials and product by use of detoxification (e.g. washing), product manufacturing (e.g. ceramic products and cement), practical applications (e.g. $\mathrm{CO}_{2}$ sequestration), and recovery of materials (e.g. $\mathrm{Zn}$ and salts). Basically, two common types of equipment for waste incineration are the fluidized bed furnace (FBF) and moving grate furnaces (MGF). These techniques differ in many aspects, such as the material used, fuel entering point, financial input, etc. Further, FBF uses an inert material such as sand in which fuel is distributed. There are two kinds of fluidized bed furnaces, the bubble fluidized bed (BFB) and the circulating fluidized bed (CFB). The BFB and CFB have major differences in the technology, involving the air flow. The inert materials are either fluidized by bubbles (BFB) or by the flow of recirculating liquid $(\mathrm{CFB})$.

Due to the relatively low heating values of typical MSW, a preferred use for the energy can be for heating and steam generation. One study suggests the allocation of a budget that includes both the waste disposal and the energy generation technology at the same time (Trehrani and Haghi 2015). One review article discussed the MSW incineration system in detail (1998 to 2018), focusing on ash characterization, dioxin emissions from fly ash, heavy metal removal, and valorization of bottom ash. It was also observed that a large proportion of studies $(35.4 \%)$ in prominent journals were reported from China (Wong et al. 2020). The use of ash from MSW incineration has been considered in various civil engineering applications such as replacement of conventional subgrade materials (Huang et al. 2020). One research carried out reviews on the MSW incineration ash specimens, with a main focus on the chemical constituents in the ash. For instance, various treatment processes such as removal of ferrous metals, separation methods, thermal methods, compaction aging during storage, solidification/stabilization, verification, chemical 
extraction, and leaching process can be used before recycling the ash (Tang et al. 2018). Thermal treatment has potential which could separate certain heavy metals from ash by forming metal chlorides at lower temperatures (Hu et al. 2013). Another study on thermal and chlorination treatment indicated that heavy metals reacted with chloride-inherent in the fly ash and approximately $80 \%$ to $89 \%$ of $\mathrm{Pb}, 48 \%$ to $56 \%$ of $\mathrm{Cd}, 27 \%$ to $36 \%$ of $\mathrm{Zn}$, and $6 \%$ to $24 \%$ of $\mathrm{Cu}$ were removed, whereas chlorinating agents dramatically improves the evaporation rate of the heavy metals (Liu et al. 2015). Bottom ash washing using natural water (rain and sea water) as pretreatment also has been suggested in the literature and removes 27 to $57 \%$ of the initial concentration of the metals in the final concentration of wash water (Quek et al. 2016). Therefore, heavy metal removal from ashes is becoming an important approach for metal recovery or as a means to reduce its potential hazards. Further, it can be used for the concrete and cement production, road payment, glasses and ceramics, agriculture, stabilizing agents, adsorbents, and zeolite production (Lam et al. 2010). Therefore, various researchers have suggested overcoming the toxic ash handling problems by resource recovery and by utilizing it in various civil engineering applications. Table 6 systematically presents fly ash and bottom ash materials for various construction activities, such as concrete (Ferraris et al. 2009), road construction (Vegas et al. 2008), tiles (Zhang et al. 2007), bricks (Zhanget al. 2011), and even raw materials for cement production (Pan et al. 2008) in several countries. Further, a hybrid cement was developed in Spain by the blending of clinker (60 wt \%) and incinerator ash (40 wt\%) (Garcia-Lodeiro et al. 2016). 
Table 5. Heavy Metals Detected in the MSW Incineration Fly Ash and Bottom Ash

\begin{tabular}{|c|c|c|c|c|c|c|c|c|c|c|c|c|c|}
\hline \multirow{2}{*}{$\begin{array}{l}\text { Types of } \\
\text { heavy } \\
\text { metals }\end{array}$} & \multicolumn{6}{|c|}{ Fly ash } & \multicolumn{7}{|c|}{ Bottom ash } \\
\hline & $\begin{array}{c}\text { (Chang } \\
\text { et al. } \\
2009)\end{array}$ & $\begin{array}{c}\text { (Funari } \\
\text { et al. } \\
2015)\end{array}$ & $\begin{array}{c}\text { (Ji et } \\
\text { al. } \\
2019)^{\star}\end{array}$ & $\begin{array}{c}\text { (Ferreir } \\
\text { a et al. } \\
2003 \text { ) }\end{array}$ & $\begin{array}{c}\text { Wu } \\
\text { and } \\
\text { Ting } \\
2006)\end{array}$ & $\begin{array}{l}\text { (Wang } \\
\text { et al. } \\
2019)\end{array}$ & $\begin{array}{l}\text { (Bayuse } \\
\text { no and } \\
\text { Schmah } \\
\text { I 2010) }\end{array}$ & $\begin{array}{c}\text { (Wu et } \\
\text { al. } \\
\text { 2016) }\end{array}$ & $\begin{array}{c}\text { (Forteza } \\
\text { et al. } \\
2004)\end{array}$ & $\begin{array}{c}\text { (Zhu et } \\
\text { al. } \\
\text { 2020)* }\end{array}$ & $\begin{array}{c}\text { (Taiwan } \\
\text { Environmental } \\
\text { Protection } \\
\text { Agency 2004) }\end{array}$ & $\begin{array}{c}\text { (Wei et al. } \\
\text { 2011) }\end{array}$ & (Funari et al. 2015) \\
\hline $\mathrm{Ag}$ & $\mathrm{N} / \mathrm{A}$ & 19.3 & $\mathrm{~N} / \mathrm{A}$ & $\mathrm{N} / \mathrm{A}$ & $\mathrm{N} / \mathrm{A}$ & $\mathrm{N} / \mathrm{A}$ & $\mathrm{N} / \mathrm{A}$ & $\mathrm{N} / \mathrm{A}$ & $\mathrm{N} / \mathrm{A}$ & $\mathrm{N} / \mathrm{A}$ & $8.5-10.7$ & $\mathrm{~N} / \mathrm{A}$ & 5.51 \\
\hline As & 93 & 21.1 & $\mathrm{~N} / \mathrm{A}$ & $\mathrm{N} / \mathrm{A}$ & $\mathrm{N} / \mathrm{A}$ & $\mathrm{N} / \mathrm{A}$ & 21 & 72 & 13 & $\mathrm{~N} / \mathrm{A}$ & $209-227$ & $<1$ & 11.9 \\
\hline $\mathrm{Ba}$ & 4300 & 1404 & $\mathrm{~N} / \mathrm{A}$ & $\mathrm{N} / \mathrm{A}$ & 539 & $\mathrm{~N} / \mathrm{A}$ & $\mathrm{N} / \mathrm{A}$ & $\mathrm{N} / \mathrm{A}$ & $\mathrm{N} / \mathrm{A}$ & 0.44 & 1104-1166 & 1126 & 1404 \\
\hline $\mathrm{Cd}$ & 470 & 114 & 0.1183 & 91 & 95 & $\begin{array}{c}0 .- \\
1600\end{array}$ & 14 & $\mathrm{~N} / \mathrm{A}$ & 3 & $\mathrm{~N} / \mathrm{A}$ & $6.8-7.8$ & 1 & 5.62 \\
\hline Co & $\mathrm{N} / \mathrm{A}$ & 21 & $\mathrm{~N} / \mathrm{A}$ & $\mathrm{N} / \mathrm{A}$ & 14 & $\mathrm{~N} / \mathrm{A}$ & 67 & $\mathrm{~N} / \mathrm{A}$ & $\mathrm{N} / \mathrm{A}$ & $\mathrm{N} / \mathrm{A}$ & $49.6-53.1$ & 5 & 35.4 \\
\hline $\mathrm{Cr}$ & 863 & 635 & $\mathrm{~N} / \mathrm{A}$ & 104 & 72 & $\begin{array}{c}1.3- \\
5120\end{array}$ & 1158 & 1244 & 900 & 0.10 & $323-439$ & 393 & 367 \\
\hline $\mathrm{Cu}$ & 1300 & 952 & 0.08 & 546 & 570 & $\begin{array}{c}41.8- \\
15700 \\
\end{array}$ & 7743 & $\sim 400$ & 500 & 0.10 & $4139-4474$ & 2321 & 3490 \\
\hline $\mathrm{Hg}$ & $\mathrm{N} / \mathrm{A}$ & 1.44 & $\mathrm{~N} / \mathrm{A}$ & $\mathrm{N} / \mathrm{A}$ & $\mathrm{N} / \mathrm{A}$ & $\begin{array}{l}0.03- \\
84.6\end{array}$ & $\mathrm{~N} / \mathrm{A}$ & $\sim 0.05$ & 2.6 & $\mathrm{~N} / \mathrm{A}$ & $\mathrm{N} / \mathrm{A}$ & $\mathrm{N} / \mathrm{A}$ & 2.70 \\
\hline $\mathrm{Mn}$ & 1600 & $\mathrm{~N} / \mathrm{A}$ & 0.005 & 338 & 309 & $\mathrm{~N} / \mathrm{A}$ & 1000 & $\sim 850$ & 2800 & 2.61 & $869-894$ & $\mathrm{~N} / \mathrm{A}$ & $\mathrm{N} / \mathrm{A}$ \\
\hline $\mathrm{Ni}$ & 124 & 85.9 & $\mathrm{~N} / \mathrm{A}$ & $\mathrm{N} / \mathrm{A}$ & 22 & $\begin{array}{l}1.23- \\
2200\end{array}$ & 356 & $\sim 45$ & 180 & $\mathrm{~N} / \mathrm{A}$ & $216-242$ & 105 & 224 \\
\hline $\mathrm{Pb}$ & 10900 & 2987 & 0.20 & 2399 & 2000 & $\begin{array}{c}61.6- \\
11300\end{array}$ & 1022 & $\sim 150$ & 2700 & 0.03 & $2474-2807$ & 687 & 1517 \\
\hline $\mathrm{Se}$ & 41 & $\mathrm{~N} / \mathrm{A}$ & $\mathrm{N} / \mathrm{A}$ & $\mathrm{N} / \mathrm{A}$ & $\mathrm{N} / \mathrm{A}$ & $\mathrm{N} / \mathrm{A}$ & $\mathrm{N} / \mathrm{A}$ & $\mathrm{N} / \mathrm{A}$ & $\mathrm{N} / \mathrm{A}$ & $\mathrm{N} / \mathrm{A}$ & $230-265$ & $\mathrm{~N} / \mathrm{A}$ & $\mathrm{N} / \mathrm{A}$ \\
\hline $\mathrm{Zn}$ & 25800 & 13417 & 0.64 & 6187 & 6288 & $\begin{array}{c}230- \\
71600\end{array}$ & 7732 & 2000 & 600 & $\mathrm{~N} / \mathrm{A}$ & $4261-4535$ & 3193 & 3562 \\
\hline Sn & $\mathrm{N} / \mathrm{A}$ & 713 & $\mathrm{~N} / \mathrm{A}$ & $\mathrm{N} / \mathrm{A}$ & $\mathrm{N} / \mathrm{A}$ & $\mathrm{N} / \mathrm{A}$ & $\mathrm{N} / \mathrm{A}$ & $\mathrm{N} / \mathrm{A}$ & 960 & $\mathrm{~N} / \mathrm{A}$ & $\mathrm{N} / \mathrm{A}$ & 111 & 201 \\
\hline $\mathrm{Sr}$ & 433 & 429 & 0.07 & $\mathrm{~N} / \mathrm{A}$ & 151 & $\mathrm{~N} / \mathrm{A}$ & $\mathrm{N} / \mathrm{A}$ & $\mathrm{N} / \mathrm{A}$ & $\mathrm{N} / \mathrm{A}$ & 0.04 & $\mathrm{~N} / \mathrm{A}$ & 271 & 440 \\
\hline $\mathrm{V}$ & 37 & 19.7 & $\mathrm{~N} / \mathrm{A}$ & $\mathrm{N} / \mathrm{A}$ & $\mathrm{N} / \mathrm{A}$ & $\mathrm{N} / \mathrm{A}$ & $\mathrm{N} / \mathrm{A}$ & $\mathrm{N} / \mathrm{A}$ & $\mathrm{N} / \mathrm{A}$ & $\mathrm{N} / \mathrm{A}$ & $\mathrm{N} / \mathrm{A}$ & 1 & 196 \\
\hline
\end{tabular}

Unit: $\mathrm{mg} / \mathrm{kg}$, *values in mass percentage 
Table 6. MSW Incineration Bottom Ash and Fly Ash Utilized in Various Applications

\begin{tabular}{|c|c|c|c|c|}
\hline $\begin{array}{l}\text { Type of } \\
\text { ash }\end{array}$ & Composition used & Applications & Country & Reference \\
\hline \multirow[t]{5}{*}{$\begin{array}{l}\text { Bottom } \\
\text { ash }\end{array}$} & $\begin{array}{l}30 \% \text { ceramic, } 40 \% \text { glass, } 25 \% \text { porous slag } \\
\text { and } 5 \% \text { metallic contents based on ferrous } \\
\text { and non-ferrous metals by weight. }\end{array}$ & Road construction & Spain & (Vegas et al. 2008) \\
\hline & $\begin{array}{l}\text { VBA filler around } 20 \% \text { (weight) used as a } \\
\text { substitute for the cement and up to } 75 \% \\
\text { (volume) of VBA as a substitute for natural } \\
\text { aggregate. }\end{array}$ & Concrete & Italy & (Ferraris et al. 2009) \\
\hline & -- & $\begin{array}{l}\text { Adsorbent of } \\
\text { pollutants in water }\end{array}$ & India & (Gupta et al. 2005) \\
\hline & Cement mixing & $\begin{array}{l}\text { Aggregate in } \\
\text { concrete }\end{array}$ & Slovenia & (Juric et al. 2006) \\
\hline & Cement production with pre-treatment & $\begin{array}{l}\text { Raw material in } \\
\text { cement industry }\end{array}$ & Taiwan & (Pan et al. 2008) \\
\hline \multirow[t]{6}{*}{ Fly ash } & $\begin{array}{l}\text { Around } 48 \% \text { (wt.) washed MSW incineration } \\
\text { fly ash and this fly ash to cement ratio used } \\
\text { were: } 70: 30\end{array}$ & $\begin{array}{l}\text { Aggregate in } \\
\text { Portland cement } \\
\text { mortars }\end{array}$ & Italy & $\begin{array}{l}\text { (Cinquepalmi et al. } \\
\text { 2008) }\end{array}$ \\
\hline & $\begin{array}{l}\text { Composition of } 20 \mathrm{SiO}_{2}-5 \mathrm{MgO}-75 \text { fly } \\
\text { ash (wt.\%) }\end{array}$ & $\begin{array}{l}\text { Manufacture of } \\
\text { ceramics }\end{array}$ & $\begin{array}{l}\text { South } \\
\text { Korea }\end{array}$ & (Park and $\mathrm{Heo} 2002$ ) \\
\hline & Cement production with pre-treatment & $\begin{array}{l}\text { Raw material in } \\
\text { cement industry }\end{array}$ & Taiwan & (Pan et al. 2008) \\
\hline & $\begin{array}{l}\text { Materials used in the optimized ratio are: } \\
\text { MSW I fly ash: red ceramic clay: feldspar: } \\
\text { sand: } \\
\text { 20: } 60: 10: 10 \text { by mass }\end{array}$ & Ceramic bricks & China & (Haiying et al. 2011) \\
\hline & $20 \%$ fly ash added in basic materials & Ceramic tiles & China & (Haiying et al. 2007) \\
\hline & $\begin{array}{l}\text { Cement/fly ash ratio increases from } 4: 6 \text { to } 8 \text { : } \\
2\end{array}$ & Landfill stabilizer & China & (Tang et al. 2016) \\
\hline Mixed ash & $\begin{array}{l}\text { Developed by the blending } 60 \mathrm{wt} \% \text { clinker } \\
\text { and } 40 \mathrm{wt} \% \text { incinerator ashes }\end{array}$ & Hybrid cement & Spain & $\begin{array}{l}\text { (Garcia-Lodeiro et al. } \\
\text { 2016) }\end{array}$ \\
\hline
\end{tabular}

\section{Gasification}

Gasification processes involve the reactions between the carbonaceous content of MSW with an oxygen-containing environment (air, oxygen, steam, and carbon dioxide) and at a temperature in the range of 550 to $1000{ }^{\circ} \mathrm{C}$. The gasification system requires some heat at the initial stage, noting that it is mainly an exothermic process, which will sustain itself accordingly (Klinghoffer and Castaldi 2013). Further, it involves the partial oxidation of a substance by the addition of oxygen such that complete combustion occurs.

WTE plants based on gasification systems that utilize the MSW as fuel are considered as highly efficient for energy generation, compared to traditional energy sources including coal, oil, and natural gas. The major product generated by gasification systems is known as syngas, producer gas, or synthetic gas. The composition of syngas is mainly hydrogen, carbon dioxide, methane, and carbon monoxide, including other constituents such as inert gases, tar, hydrocarbons, and gaseous pollutants, which can be 
measured in the syngas (AV. 1994). It has been experimentally found that syngas consists of $13 \pm 2$ vol\% CO, $11 \pm 0.4$ vol\% CO, $3.2 \pm 0.2$ vol\% $\mathrm{CH}_{4}, 12 \pm 2 \mathrm{vol}_{\%} \mathrm{H}_{2}, 2.9 \pm 0.3$ vol\% $\mathrm{C}_{2}-\mathrm{C}_{5}$ gases, and $58 \pm 4$ vol\% $\mathrm{N}_{2}$ etc. (Chan et al. 2019). The overall gasificationbased syngas products have a net calorific value of 4 to $10 \mathrm{MJ} / \mathrm{N} \mathrm{m}^{3}$. Syngas purification is needed to obtain cleaned gas that can be used to generate power in the forms of electricity, heat, or steam, which can be used directly or fed into the grid. Further, gasification can be divided into two categories, mainly direct and indirect gasification. Direct gasification is based on the partial oxidation of feed materials, whereas the indirect process takes place without the aid of a gasification agent (Al 1997). Indirect gasification is performed without $\mathrm{O}_{2}$ injection and contains nitrogen as impurities, which further decrease the volume and heating value of the syngas (Paisley and Anson 1998). The gasification system as a direct process having pure oxygen has some advantages over the indirect process. In fact, pure oxygen production is an expensive process that is expected to account for more than $20 \%$ of the total cost of the electricity production (Della 2001).

In general terms, a gasification system consists of three stages (Seo et al. 2018):

(a) Gasifier for producing synthetic gas.

(b) Cleaning system for the pollutants removal and toxic compounds.

(c) Energy recovery system includes a gas engine.

However, sub-systems are also needed to handle the environmental impacts from the gasification in the form of air pollutants, wastewater, and solid residues. Various studies have been reported on the gasification system for the municipal solid waste. A few years ago, WTE systems with different types of gasification were applied in several countries, such as a semi-industrial fluidized bed plant (Couto et al. 2016), a "two-step" facility (Tanigaki et al. 2012), a downdraft gasifier (Bhoi et al. 2018), a fixed bed gasifier (Tańczuk et al. 2019), and a pilot plasma furnace (Materazzi and Taylor 2019). The operating parameters such as temperature, residence time, oxygen concentration, equivalent ratio, carbon conversion efficiency, and tar content, etc., have important roles in the syngas production. Thus, one recent report investigated the effects of varying temperature and oxygen concentration for syngas generation from daily generated MSW. The combustible gas yield and lower heating value of syngas observed were $0.296 \mathrm{~L} / \mathrm{g}$ and $10.98 \mathrm{~kJ} / \mathrm{L}$, respectively at $650{ }^{\circ} \mathrm{C}$ temperature and $1.25 \%$ oxygen concentration (Gu et al. 2020). Researchers also investigated the role of temperature on syngas composition; biomass conversion efficiency was correlated to temperature and solids residence time, with the carbonation of $\mathrm{CaO}$ used as bed material in the gasifier studied conditions (Martínez et al. 2020). Increased temperature was shown to improve the gasification process, and higher air equivalence ratio increased the carbon conversion ratio and decreased the lower heating value of syngas. Further, moisture content has been found to increase the carbon conversion and heat conversion efficiency at lower ratios (Chen et al. 2010). Temperature and steam rate varying from 700 to $900{ }^{\circ} \mathrm{C}$ and 2.5 to $10 \mathrm{~mL} / \mathrm{min}$, respectively, were found to influence the pyrolysis process. It was observed that hydrogen gas increased significantly with an increase in the waste marble power to MSW mass ratio, while carbon dioxide decreased (Irfan et al. 2019). A co-gasification process also can be utilized with the application focusing on the preserving non-renewable resources such as coal and simultaneously finding a better usage for MSW. Hence, one study (Tanigaki et al. 2012) investigated the influence of co-gasification of MSW with and without the bottom ash. No significant difference was found in power generation with $18.9 \%$ the bottom ash and $23.0 \%$ 
without MSW. However, the carbon conversion ratios were as high as $91.7 \%$ and $95.3 \%$, respectively. Another work (Bhoi et al. 2018) utilized the co-gasification ratios of 0, 20, and $40 \%$ with a capacity of $100 \mathrm{~kg} / \mathrm{h}$ commercial scale downdraft gasifier. Satisfactory results were shown for up to $40 \%$ co-gasification, and heating values of syngas measured were the $6.2,6.5$, and $6.7 \mathrm{MJ} / \mathrm{Nm}^{3}$ with the co-gasification ratios of 0,20 , and $40 \%$, respectively.

Further, in comparison with the incineration, gasification processes can reduce or inhibit the formation of environmental pollutants such as dioxin and furans. Besides these, chloride species $(\mathrm{KCl}, \mathrm{HCl}$, and $\mathrm{NaCl})$ can be eliminated from the syngas by using a purification system, which further decreases the potential of dioxin and furans in downstream applications (Arena 2012; Zhang et al. 2018). On the other hand, it has been reported that the economic and environmental performances of MSW gasification have some advantages and that gasification processes can also be operated commercially (Fernández-González et al. 2017). One example can be seen of MSW gasification that is a commercial power plants in Japan, which carried out MSW gasification, achieved carbon conversions higher than the $91.7 \%$, and concentrations of dioxins and heavy metals were lower than the limits (Tanigaki et al. 2012).

\section{Pyrolysis}

Pyrolysis of municipal solid waste is carried out in a pyrolyzer in the relative absence of oxygen. The temperature is maintained between $300^{\circ} \mathrm{C}$ and $800^{\circ} \mathrm{C}$ during the pyrolysis process, and initially external heat is supplied as required to begin the process. The temperature is maintained depending upon the raw materials present in the solid waste. Before the inlet point of the pyrolyzer, pre-treatment of MSW is required to separate the metals, glass, and inert materials. The thermal degradation process in the heating chamber generally starts with a temperature of $300{ }^{\circ} \mathrm{C}$, which begins with consumption of the oxygen initially present, as well as some initial degradation of organic materials. Thereafter, an oxygen-free environment is maintained, and the temperature is increased up to $800^{\circ} \mathrm{C}$ in a non-reactive environment (Fig. 4). The final products from pyrolysis of solid wastes are gases, liquid, and solid residues. The gases generated are known as syngas or synthetic gases and mainly include methane, hydrogen, carbon dioxide, and carbon monoxide.

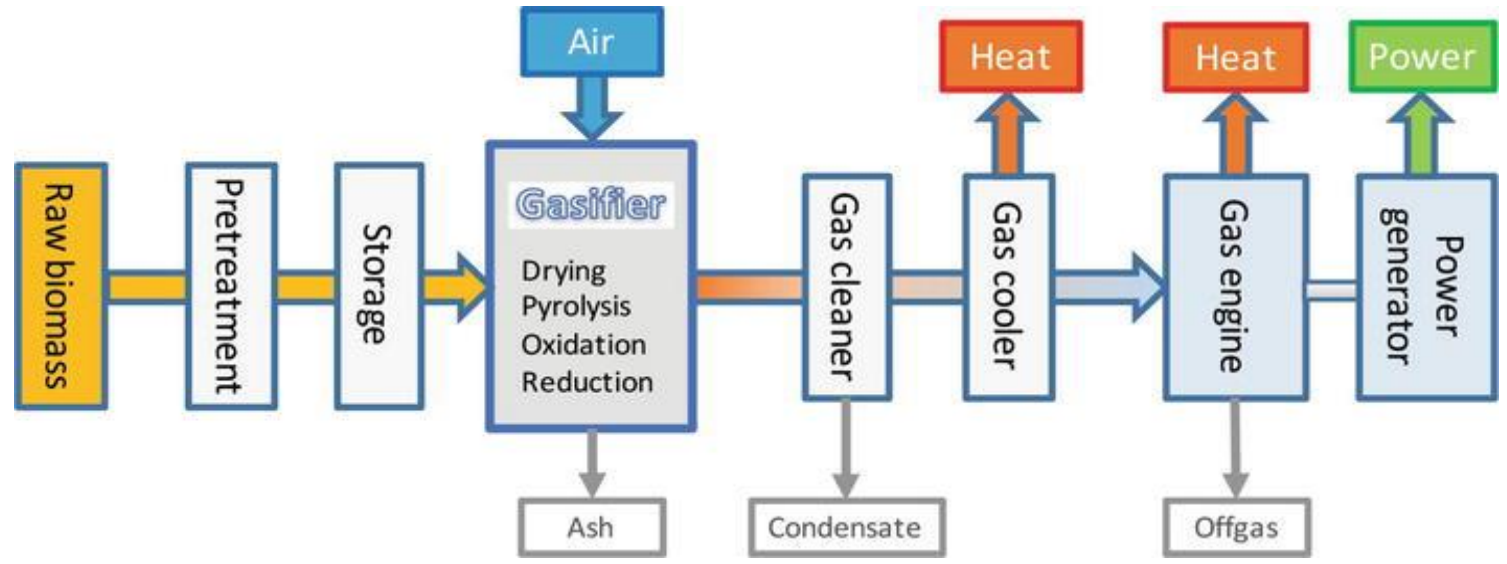

Fig. 4. Process of gasification (adapted from Koido \& Iwasaki, 2017, published under CC BY 3.0 license) 
Pyrolysis of solid waste is considered to be an innovative alternative for the treatment of MSW, in addition to generating various chemicals and fuels (Malkow 2004). Pyrolysis has an advantage over the traditional incineration plants in terms of providing a clean process by generating lower amounts of air pollutants (dioxin, nitrogen oxides, and sulphur oxides). Further, these pollutants can be easily washed from synthetic gas, thereby avoiding their release into the atmosphere (Chen et al. 2014). Char, which is another product of pyrolysis, is considered as a low-grade fuel. Sometimes it can be toxic due to mixing of industrial solid waste. One study (Bernardo et al. 2010) investigated the copyrolysis of different wastes (used tires, pines biomass, and plastics) and char residues containing inorganic toxic metals such as $\mathrm{Hg}, \mathrm{As}, \mathrm{Pd}, \mathrm{Cd}, \mathrm{Cu}$, and $\mathrm{Zn}$. Thus, it is usually not suggested to mix industrial solid waste into household waste for pyrolysis. A review article has summarized the influence of operating parameters such as heating rate, temperature, and residence time in the reaction zone relative to the pyrolysis process and the end products (Chen et al. 2014). MSW in the form of refuse-derived fuel may have advantages in the form of adaptability to the various types of reactor, and products generation such as oil, gas, and char products at $600^{\circ} \mathrm{C}$ or more. Another work (Xue et al. 2016) involved the catalytic based co-pyrolysis of biomass and polyethylene (PE) in a tandem micro-pyrolzer using ZSM-5 as catalyst. Depolymerization of lignin was strongly promoted by PE, as the yields of different phenolic monomers increased up to $43 \%$, along with pyrolysis products, i.e. char and carbon oxides produced from biomass when copyrolyzed with PE.

Studies have been done comparing MSW and municipal plastic wastes (MPW) to produce pyrolysis oil at a temperature of $500{ }^{\circ} \mathrm{C}$, followed by comparison with commercial oil. It was found that MPW with or without catalyst meets the required standard of commercial oil, whereas MSW pyrolyzed oil has a high water content (Miskolczi et al. 2013). It can be seen from the literature that plastic materials in municipal solid waste need higher temperature to complete pyrolysis process, and major products generated are oil and liquid products, as well as $\mathrm{HCl}$ due to the presence of polyvinyl chloride (PVC). Pyrolysis of vegetables has been found to give a gas yield of $0.388 \mathrm{Nm}^{3} \mathrm{~kg}^{-1}$ (dry basis) at $850{ }^{\circ} \mathrm{C}$ temperature, moisture content of $17.9 \%, 17.6 \%$ tar, and $32 \%$ char generation under a rotary kiln (Li et al. 2000). Artificially prepared MSW having a composition of 8.5\% PVC, 8.3\% rubber, $24.3 \%$ kitchen waste, $8.5 \% \mathrm{PE}, 7.3 \%$ vegetables, $5.4 \%$ cloth, $14.6 \%$ pericarp, $18.2 \%$ paper, and $4.87 \%$ saw dust was studied for pyrolysis at a temperature of 500 to 700 ${ }^{\circ} \mathrm{C}$. The observations indicated that gas yield and oil yield increased from $24.4 \%$ to $38.9 \%$ and $21 \%$ to $16.4 \%$, respectively, and the average claorifc value of thegas was $7.5464 \mathrm{MJ}$ $/ \mathrm{m}^{3}$ at $600{ }^{\circ} \mathrm{C}(\mathrm{Li}$ et al. 2007). A review article focused on the sustainable and efficient pyrolysis method for plastic waste with advantages in decreasing the carbon footprint minimizes the air emissions instead of gasification and incineration. Thus, the influence of various catalysts on the pyrolysis was evaluated, and there was a comparative assessment with thermal and plastic waste treatment in the presence of catalysts (Al-Salem et al. 2017). Garden waste and wood pellets were studied in a pilot-scale rotary kiln pyrolysis at temperatures ranging from 700 to $900{ }^{\circ} \mathrm{C}$. The results at a temperature above $700{ }^{\circ} \mathrm{C}$ showed that the volatile matter produced was more than the $80 \%$ (wt.) and syngas (CO+ $\mathrm{H}_{2}$ ) content was higher than the $59 \mathrm{~mol} \%$. For the char and other products, the yield was below $20 \mathrm{wt} \%$ with the higher heating value of $29 \mathrm{MJ}$ per $\mathrm{kg}$ and an $80 \%$ carbon content with the predominance of benzene and naphthalene by GC/MS (Tanoh et al. 2020).

Plasma pyrolysis involves volumetric heating and is regarded as an advanced technique as compared to conventional thermal pyrolysis (Hrabovsky et al. 2006) and 
microwave pyrolysis (Macquarrie et al. 2012). Thus, in plasma pyrolysis the heating of MSW is carried out at a high temperature of over $1000{ }^{\circ} \mathrm{C}$ using plasma torches without an air supply. The process converts waste materials into syngas, which is mainly $\mathrm{H}_{2}, \mathrm{CO}$, and other end products, such as vitrified matrix. Products generated from plasma pyrolysis are suitable for energy recovery and materials recycling, and there are reduced negative impacts to environment and human health (Huang and Tang 2007). However, a disadvantage of plasma technique is the requirement of a huge amount of secondary energy, e.g. $1 \mathrm{~kW} \mathrm{~h} \mathrm{~kg}^{-1}$ for arc plasma technology (Wang and Huang 2008).

\section{Landfill Gas Generation}

Thermal energy conversion systems for MSW are increasing in the developed countries due to land constraints in recent decades. However, in developing countries still the landfilling of solid waste is in practice in large numbers. One study from Brazil indicated that very limited thermal treatment of solid waste is operational because of the priority of use of landfills due to large land availability around the metropolitan cities (de Souza et al. 2014). One region in Brazil achieved 53\% collection of solid waste generated and $41.94 \%$ of total waste i.e. 55.5 million tonnes went to sanitary landfills in 2011 (ABRELPE 2011). It was predicted that $85 \%$ of the world's MSW is dumped into the landfills, and major concerns are the uncontrolled release of gaseous emissions and effects on climate change (Njoku et al. 2018). Another report (Scarlat et al. 2015) focused on the African countries, i.e. South Africa, Algeria, Cameroon, Madagascar, Mauritius, Morocco, Niger, and Tunisia, which disposed approximately 95\%, 97\%, 95\%, 96\%, 91\%, 96\%, 64\%, and $95 \%$, respectively, of their waste into landfills.

Sanitary landfills are in practice in high-income countries for waste disposal. These landfills degrade the waste by chemical and biological processes, and release is avoided by use of collection systems for leachates and methane gas. The basic requirements for the sanitary landfills is the partial hydrogeological conditions isolation, engineering aspects, control for the leachate and gas, and planning for waste placement and proper covering. In developing countries, unsanitary MSW disposal practices are in use, which have negative environmental impacts and the public health concerns (Finnveden et al. 2005). MSW composition in landfills starts the degradation biologically under the anaerobic conditions, and landfill gases (LFGs) are generated from anaerobic decomposition process (Ahmadian et al. 2013; Jain et al. 2014) (Fig. 5). As per the Environmental Protection Agency (2020), landfill gases are composed of roughly 50\% methane, 50\% carbon dioxide, and a small amount of water vapor and other gases (U.S. Envrionmental Protection Agency 2020). Further, the landfill degradation can be enhanced by promoting moisture content, the most significant factor responsible for providing important factors for microorganisms in landfills for the decomposition (Al-Kaabi et al. 2006). The maximum gas production could be enhanced by the addition of liquid (leachate, water, or storm water runoff) in the waste biomass to reach 35 to $40 \%$ water by weight (Christensen and Kjeldsen 1989). Further, methane is considered to be a greenhouse gas; because of its relatively high global warming potential, it is important to install collection systems for methane gas (Bruce et al. 2017). On the other hand, $\mathrm{CH}_{4}$ can cause explosions if the air volume reaches 5 to $15 \%$ due to heat value equivalent to the white oil. Taking proper precautions, methane gas from landfills could be utilized as a cost-effective method for the heat and electricity generation (Weber and Stadlbauer 2017). One report (U.S. Energy Information Administration 2019) estimated that 352 landfills in USA generate and collected the landfill gas of 270 billion cubic feet (BCF) and approximately 11 billion kilowatt-hours (kWh) of electricity was 
produced. This is further estimated to be around $0.3 \%$ of total U.S. utility-scale electricity generation. An Environmental Protection Agency (U.S. Envrionmental Protection Agency 2020) report says that about $72 \%$ of currently operational LFG energy plants are generating electricity in the United States. Various technologies such as turbines, micro-turbines, internal combustion engines, and fuel cells can be used to generate power onsite as well as for sale to the power grid.

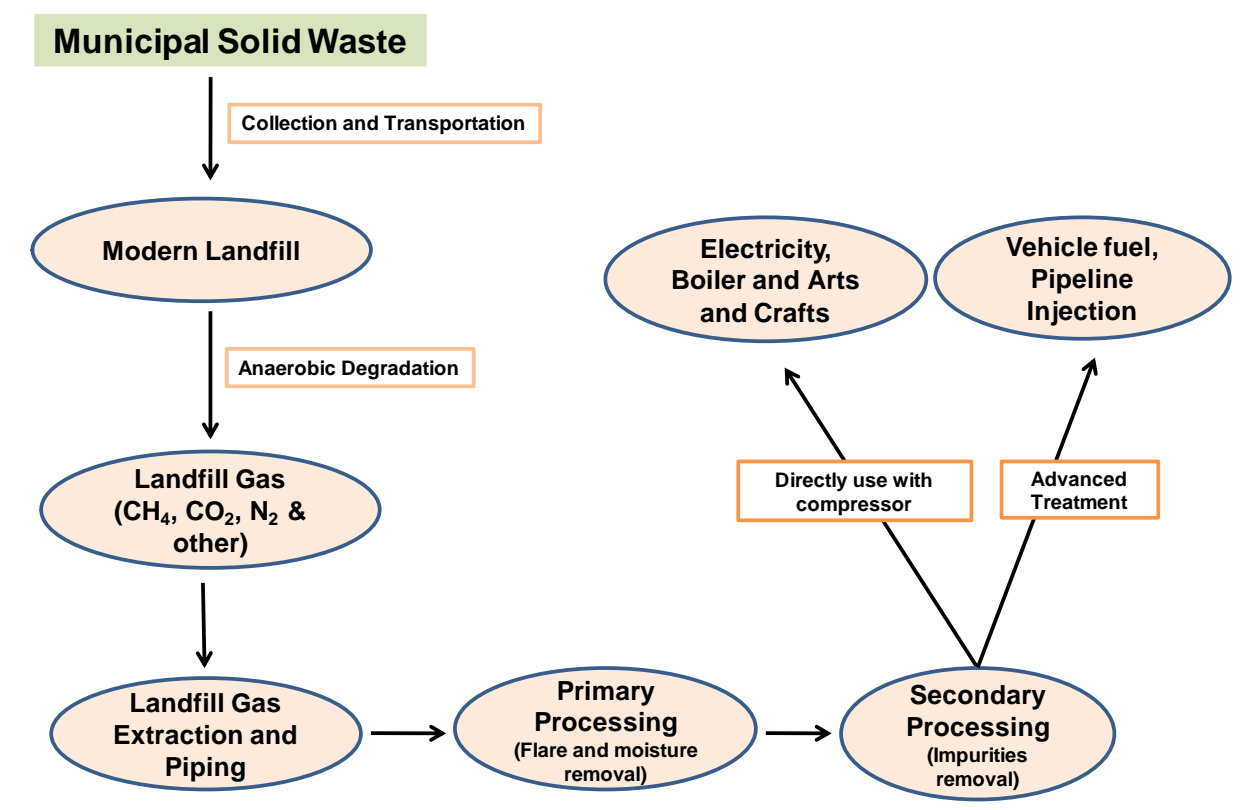

Fig. 5. Modern Landfill for Energy Recovery

LFGs emission is dependent upon the waste composition, waste compaction, rate of the degradable organic fraction, leachate recirculation, and environmental factors (Lou and Nair 2009; Wangyao et al. 2010). USEPA model parameters were used in various previous studies for estimation of methane gas production potential in landfills. Further, according to this model, and as noted in the literature, gas production can reach $170 \mathrm{~m}^{3}$ per ton of waste (Al-jaf and Al-Ameen 2019). For instance, MSW having higher percentage of biodegradable waste leads to the higher gas production potential $\left(200 \mathrm{~m}^{3} / \mathrm{ton}\right)$, which is also evidenced in previous studies (Ghasemzade and Pazoki 2017; Fernandes et al. 2018). Two studies (2013 and 2017) were performed in the Sanandaj and Jifrot city of Iran using LandGem software for the estimation of landfill gases. It was predicted that Sanandaj city produces gas production in the range of $200 \mathrm{~m}^{3}$ per ton; the estimated quantities of the landfill gas, methane, carbon dioxide, and non-methane organic compounds (NMOC) for 20 years will be 23,$150 ; 6,184 ; 16,970$; and 266 tons/year, respectively (Rezaee et al. 2014). Jifrot city of Iran observed a gas production potential of $198 \mathrm{~m}^{3} /$ ton. The highest content observed for methane, carbon dioxide, and NMOC in 30 years will be 40,590; 112,700; and 1,765 tons $/ \mathrm{m}^{3}$, respectively (Ghasemzade and Pazoki 2017). Recent research (Srivastava and Chakma 2020) estimated the LFG emissions from the three landfill sites (Ghazipur, Bhalswa, and Okhla) of Delhi (India) using the three landfill gas generation model, i.e. IPCC default model, first order decay model, and land GEM. Methane generation was estimated to be about 2,444; 1,115; and 1,643 gigagram (Gg) using default, first order decay, and land GEM, respectively until 2030. Further, the Yedla technique has been used to estimate the energy recovery potential, which was found to be about 5784 
terajoule (TJ) by using an energy recovery system. One of the previous works cites the use of saline water for the biodegradation of LFG generated from landfill bioreactors. The experimental observations indicated that the rate and volume of gas generation are similar to fresh water recirculation in the landfills, and saline water could be utilized for biodegradation of waste in the landfills (Hossain et al. 2014).

\section{Biochemical Conversion of MSW to Bioenergy Products}

MSW conversion into various kinds of energy products have been carried out through thermal, biochemical, and landfilling technologies. Biochemical conversion involves the digestion of biomass with microorganisms and their enzymes. The end products of the biochemical conversion are methane, hydrogen, ethanol, or other valueadded product. The biochemical process is environmentally friendly and cost-effective alternative that generates energy from wastes. Biogas production by anaerobic digestion and fermentation are the most common biochemical practices for utilization of MSW (Eddine and Salah 2012; Vaish et al. 2016; Beyene et al. 2018).

Pretreatment of OFMSW is important step that is dependent on characteristic of substrate and improves the efficiency of biochemical processes. The variation in composition of OFMSW represents the main obstacle for determination of most suitable pretreatment for the biochemical processes.

\section{Biogas production by anaerobic digestion}

Biogas is a clean and renewable form of energy that can substitute for conventional energy sources such as fossil fuels, oil, etc. Anaerobic digestion (AD) or biomethanation is the microbial process that converts biomass into biogas in the absence of oxygen. Biogas mainly consists of methane $\left(\mathrm{CH}_{4}\right)$ and carbon dioxide $\left(\mathrm{CO}_{2}\right)$, and it is used as a fuel for local needs or for electricity generation. Biogas can be cleaned and upgraded to biomethane that is used as vehicle fuel. Biomethane is combusted in an internal combustion engine of vehicles (Mayer et al. 2014; Zheng et al. 2014; Kumar et al. 2016). The maximum conversion of organic wastes (carbohydrates, lipids, and proteins) is achieved during AD (Kumar et al. 2019). AD generally consists of four steps that are hydrolysis, acidogenesis, acetogenesis, and methanogenesis (Fig. 6). These steps run simultaneously because of the physiological dependence of microorganisms involved in different steps of AD. The degradation products from one group of microorganisms are the substrate for another group of microorganisms and require a close spatial proximity (Theuerl et al. 2019). Microorganisms are the core of AD process, and the biochemical processes of AD are performed by a diversity of microorganisms (Wang et al. 2018).

Hydrolysis is the first step of AD that is performed by hydrolytic microorganisms. The efficiency of biogas production mainly depends on the hydrolysis of carbohydrates, proteins, and lipids. It is slowest step of biogas production process and known as the ratelimiting step of the whole process. Organic matter is broken down to mono- and oligomers (reducing sugars, amino acids, peptides, free fatty acids) by extracellular enzymes during hydrolysis (Barbot et al. 2016). Lignocellulosic biomass is recalcitrant to microbial attack and enzymatic hydrolysis and it is most commonly available waste that is used for biogas production.

The microorganisms that hydrolyze carbohydrates include various bacteria and anaerobic fungi. Lignocellulosic biomass and starch available in waste biomass are hydrolyzed by anaerobic microorganisms including the group Acetovibrio, Cellulomonas, Clostridium, Caldanaerobacter, Caldicellulosirrutor, Bacillus, Butyrivibrio, Bacteroides, 
Thermomonospora, Ruminococcus, Ruminonoclostridium, Baceriodes, Fibrobacter, Fervidobacterium, Erwinia, Microbispora, Streptomyces, Eubacterium, Halocella, and Paludibacter, etc. (Azman et al. 2015; Boone et al. 1993; Gerardi 2003; Jain et al. 2015; Lo et al. 2009; Nzila 2017; Wang et al. 2009; Westerholm and Schnürer 2019). Among anaerobic fungi, members of the phylum Neocallimastigomycota are commonly available in ruminants and improve biogas production by the hydrolysis of lignocellulosic biomass (Westerholm and Schnürer 2019; Wu et al. 2018).

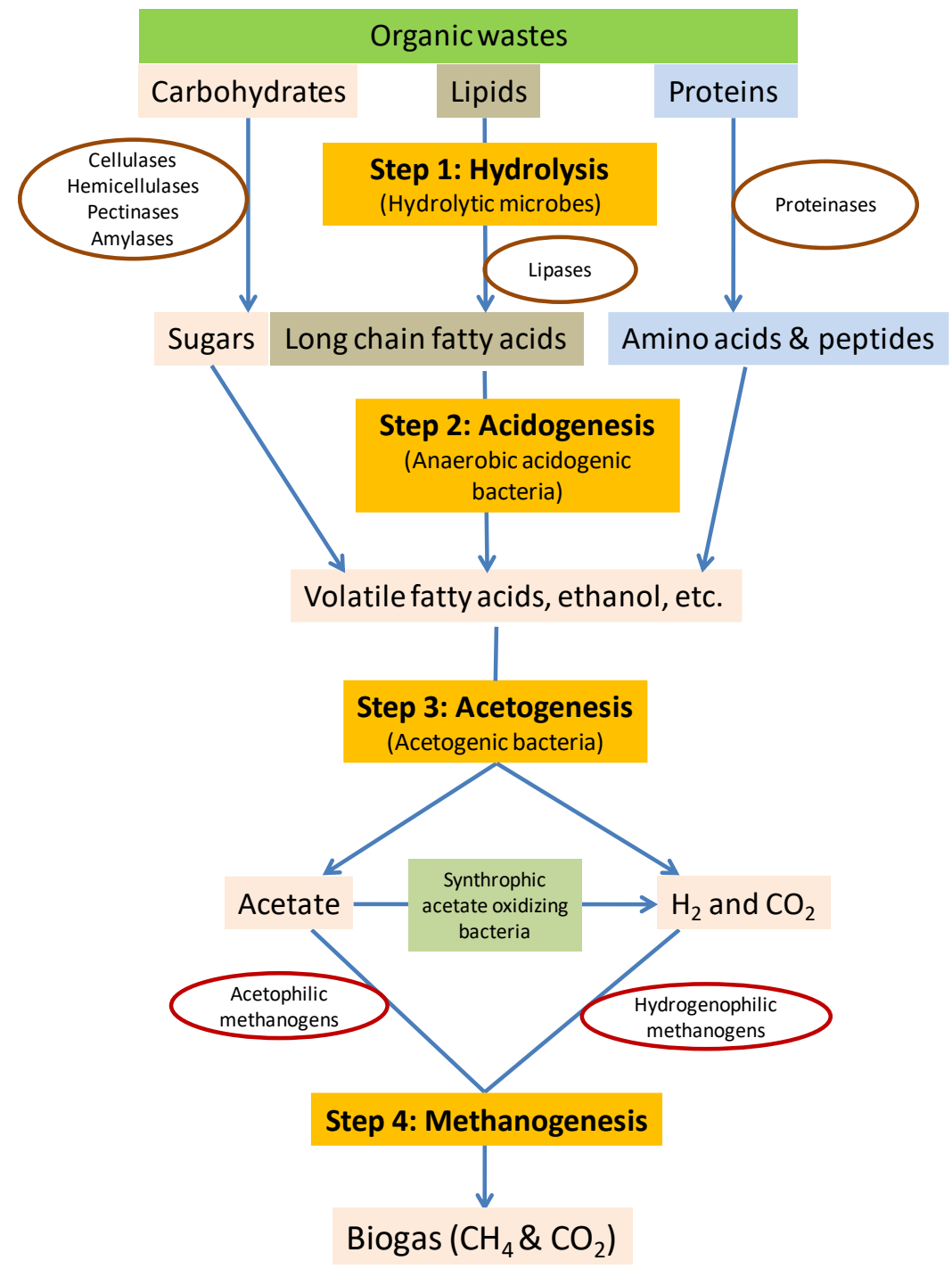

Fig. 6. Anaerobic digestion process

Acidogenesis is the second step of AD of organic wastes, utilizing the monomers generated during the previous step to produce volatile fatty acids (VFAs). Butanoic, propionoic, ethanoic, and lactic acids are the main VFAs that are generated during acidogenesis by bacteria known as acidogenic or fermentative bacteria. Besides VFAs, simple molecules such as ethanol, $\mathrm{CO}_{2}$, and $\mathrm{H}_{2}$ are also generated during this step of $\mathrm{AD}$ (Nzila 2017; Theuerl et al. 2019). The third step of AD is acetogenesis, which involves the conversion of VFAs into acetate by acetogenic microorganisms. During the process of acetogenesis $\mathrm{H}_{2}$ and $\mathrm{CO}_{2}$ are also generated due to the activity of synthrophic acetate 
oxidizing bacteria (SAOB). Acetate, $\mathrm{H}_{2}$ and $\mathrm{CO}_{2}$ are the methanogenic substrates that are used by methanogens for methane generation (Jain et al. 2015; Nzila 2017). The microorganisms belong to different genera such as Acetobacterium, Clostridium, Eubacterium, Ruminococcus, Syntrophomonas, Sporomusca, Syntrophospora, and Thermosyntropha, which are involved in the process of acetogenesis (Jain et al. 2015; Nzila 2017).

Methanogenesis is the fourth step and final step of AD that is performed by the methanogenic microorganisms under strictly anaerobic conditions. In this stage, bacteria convert $\mathrm{CH}_{3} \mathrm{COOH}$ and $\mathrm{H}_{2}$ into $\mathrm{CO}_{2}$ and $\mathrm{CH}_{4}$. The bacteria responsible for $\mathrm{CH}_{4}$ generation are known as methanogens, and they are highly vulnerable to small amounts of oxygen. The methanogens are slow growing and extremely sensitive to changes in the environment. They can absorb and digest the simplest of molecules. The reaction equations representing the process of methanogenesis during AD are following (Balat and Balat 2009; Adekunle and Okolie 2015; Anukam et al. 2019):

$$
\begin{gathered}
\mathrm{CH}_{3} \mathrm{COOH} \rightarrow \mathrm{CH}_{4}+\mathrm{CO}_{2} \\
\mathrm{CO}_{2}+4 \mathrm{H}_{2} \rightarrow \mathrm{CH}_{4}+2 \mathrm{H}_{2} \mathrm{O} \\
2 \mathrm{CH}_{3} \mathrm{CH}_{2} \mathrm{OH}+\mathrm{CO}_{2} \rightarrow \mathrm{CH}_{4}+2 \mathrm{CH}_{3} \mathrm{COOH}
\end{gathered}
$$

Methanogens are obligate obligate anaerobes that belong to the domain archaea and the phylum Euryarchaeota. Based on the substrate utilization, methanogens are classified into four groups: (1) methanogens that use $\mathrm{H}_{2} / \mathrm{CO}_{2}$ and formate as substrates include the genera Methanobacterium,Methanobrevibacter, and Methanogenium; (2) methanogens that use acetate as the substrate e.g. Methanosaeta; (3) methanogens that can utilize acetate, $\mathrm{H}_{2} / \mathrm{CO}_{2}$, and methyl compounds as the substrates include the genera Methanosarcina; (4) methanogens that can metabolize methyl compounds like methanol e.g. Metahnolobus and Methanococcus (Chaudhary et al. 2013; Garcia 1990). AD generates biogas that contains $\mathrm{CH}_{4}, \mathrm{CO}_{2}, \mathrm{H}_{2}, \mathrm{H}_{2} \mathrm{~S}, \mathrm{NH}_{3}$, siloxaine, and other substances. Research has been carried out for the purification of biogas, especially for $\mathrm{H}_{2} \mathrm{~S}, \mathrm{NH}_{3}$, and siloxaine removal, since these compounds inhibit $\mathrm{AD}$ and also cause serious human health and environmental problems (Chen et al. 2008; Molino et al. 2013). The combustion of unclean biogas in steam turbines and cooking stoves releases pollutants such as SOx and NOx gases that are corrosive and result in the wearing down of the economy through frequent repair of infrastructure and on respiratory related illness. Moreover, siloxane results in the accumulation of $\mathrm{SiO}_{2}$ in stove burners and pipes that may lead to their blockage (Makauki et al. 2017).

\section{MSW as substrate for biogas production}

AD of Organic Fraction of Municipal Solid Waste (OFMSW) is an environmentally sustainable alternative for waste management. During AD of OFMSW, energy is recovered in the form of biogas. The biogas production mainly depends on the type and amount of macromolecules available in OFMSW. The definition of OFMSW has variations depending upon the regions and the nations. The mixture of food, garden wastes, and paper is considered OFMSW in USA, while in European Union, OFMSW is considered a mixture of wastes from parks, gardens, and kitchens. During the last years, several researchers, companies and governmental agencies are actively working to improve the AD process of OFMSW to recover energy (Campuzano and González-Martínez 2016; Palmisano and Barlaz 1996). The characteristics and the composition affect the quality of digestate and the biological process. Therefore, several researchers have studied the relationship of 
biogas production and OFMSW characteristics such as particle size, type of components, molecule type, elementary composition, and bromatological properties (Al Seadi and Lukehurst 2012; Browne and Murphy 2013; Melts et al. 2014; Campuzano and GonzálezMartínez 2016).

Hydrolysis of substrate is the rate limiting step during AD, and it is especially slow in the case of solid substrate. Therefore, a suitable pretreatment is required for solid substrate to accelerate the rate of hydrolysis. Different types of pretreatments such as physical, chemical, biological, and their combinations have been considered to assist AD of OFMSW. Mechanical pretreatments have been found to be most reliable for AD of OFMSW. Shredding is the most common process that is employed at industrial plants. It reduces particle size and improves the available surface area for microbial action that facilitates the solubilisation of organic matter (Cesaro et al. 2014; Allegue et al. 2020). Recently, several other mechanical and thermal pretreatment methods such as thermal hydrolysis, press-extrusion, sonication, high pressure homogenization, and hydrothermal are being tested and are under the research and development (Paritosh et al. 2018; Allegue et al. 2020; Cesaro et al. 2021). Another group of researchers has questioned the benefits of size reduction and given attention to other important factors. It has been argued that the extensive size reduction has no significant benefit during $\mathrm{AD}$, and it requires higher energy input that makes the process uneconomic. In unmixed dry digestion system, a small size may be disadvantageous due to 'slumping' of waste within the digester, which makes it more difficult to handle (Chynoweth et al. 1993; Gunaseelan 1997; Vandevivere et al. 2003).

Depending on the solids content in the bioreactor, AD can be divided into dry and wet processes. The reaction time for biogas production depends on the composition of the substrate and it ranges from 15 to 30 days due to complexity of OFMSW. The shorter reaction times have been observed for wet $\mathrm{AD}$, which is performed with solids within the range 10 to $15 \%$ (Campuzano and González-Martínez 2015). Biogas production depends on the substrate characteristics, its biodegradability, and the contents of carbohydrates, proteins, and lipids. The contents of cellulose, hemicelluloses, and lignin also affect the biogas production. The lignin content in OFMSW is regarded as a negative indicator of microbial degradation (Hartmann and Ahring 2006; Campuzano and González-Martínez 2015). Temperature is another crucial factor that affects the biogas production. Temperature in the digester has a significant effect on microbial growth and biogas production. AD takes place in psychrophilic $\left(<30{ }^{\circ} \mathrm{C}\right)$, mesophilic $\left(30\right.$ to $\left.40{ }^{\circ} \mathrm{C}\right)$, and thermophilic $\left(50\right.$ to $\left.60{ }^{\circ} \mathrm{C}\right)$ conditions. However, anaerobes are most active in mesophilic and thermophilic conditions (Kigozi et al. 2014). The performance of laboratory-scale reactor $(5.0 \mathrm{~L})$ was evaluated by treating two types of OFMSW, including source sorted OFMSW (SS_OFMSW) and mechanically selected OFMSW (MS_OFMSW). The reactor was operated at thermophilic $\left(55^{\circ} \mathrm{C}\right)$ and dry (20\% total solids) conditions, and mesophilic digested sludge was used as inoculum. SS_OFMSW showed a $45 \%$ of volatile solids (VS) removal with a cumulative biogas of $120 \mathrm{~L}$ in approximately 60 days. MS_OFMSW gave a higher level of organic degradation (56\% VS removal) and the biogas production was 82 L (Forster-Carneiro et al. 2008). Fernandez-Rodriguez et al. (2013) compared mesophilic $\left(35^{\circ} \mathrm{C}\right)$ and thermophilic $\left(55^{\circ} \mathrm{C}\right)$ AD of OFMSW under dry conditions (20\% TS). The maximum growth rate was reported as 27 to $60 \%$ higher for thermophilic process compared to mesophilic conditions. Therefore, same level of organic matter degradation and methane production was achieved in a shorter time duration, 20 days for thermophilic AD, compared to 40 days for mesophilic AD (Fernández-Rodríguez et al. 2013). 
The integrated rotator drum reactor (RDR) and anaerobic-phased solids digester systems have been developed for biogas production from MSW. The pretreatment of MSW was carried out in a commercial RDR to generate organics from MSW. The organics produced from RDR contained $50 \%$ total solids (TS) and $36 \% \mathrm{VS}$ on a wet basis. The organics were digested in a laboratory APS-digester system with the organic loading rate (OLR) of 3.1, 4.6, 7.7, and 9.2 $\mathrm{gVSL}^{-1} \mathrm{~d}^{-1}$. At the OLR of $9.2 \mathrm{gVSL}^{-1} \mathrm{~d}^{-1}$ the biogas production rate was $3.5 \mathrm{~L} \mathrm{~L}^{-1} \mathrm{~d}^{-1}$ and the biogas and methane yields were 0.38 and 0.19 $\mathrm{gVS}^{-1}$. The total VFAs concentration reached a peak value of $15,000 \mathrm{mg} \mathrm{L}^{-1}$ as acetic acid in the first $3 \mathrm{~d}$ of batch digestion and decreased thereafter (Zhu et al. 2010).

\section{Biogas production by co-digestion of OFMSW and other substrates}

Co-digestion of different substrates improves the operation of $\mathrm{AD}$ and offers several ecological, technological, and economical advantages, compared to single substrate digestion. However, the combination of different substrates needs to be selected very carefully for the efficiency improvement of AD (Brown and Li 2013; Rughoonundun et al. 2012). Co-digestion of substrates balances the macro-and micronutrients, $\mathrm{C} / \mathrm{N}$ ratio, $\mathrm{pH}$, inhibitors/toxic compounds, biodegradable organic matter, and dry matter. Moreover, codigestion of organic substrates is an effective way to improve the load of biodegradable matter, digestion stability, and methane production (Hartmann et al. 2004; Rughoonundun et al. 2012; Wang et al. 2014). The nutrient-rich substrates are suitable for co-digestion with nutrients-poor substrates. Some of the organic substrates have low $\mathrm{C} / \mathrm{N}$ ratio that can be co-digested with substrates having higher $\mathrm{C} / \mathrm{N}$ ratio (Rughoonundun et al. 2012). The different types of industrial organic wastes (IOW) and OFMSW can be co-digested for energy generation. The most difficult organic wastes generated by industries of municipalities are those that are rich in lipids, cellulose, and proteins. Lipids are fats, oils, or greases that are found in wastes from the food industry, slaughterhouses, dairies, or fat refineries. Lipids have high theoretical methane potential; therefore, they are attractive sources for biogas production. Lipids can inhibit the activity of methanogenic bacteria (Ponsá et al. 2011). Cellulosic wastes (CW) such as paper or cardboard are also part of MSW that is not source-separated. The $\mathrm{C} / \mathrm{N}$ ratio of $\mathrm{CW}$ is in the range 173:1 to greater than 1000:1, while the suggested optimum $\mathrm{C} / \mathrm{N}$ ratio for anaerobic digestion is in the range of 20:1 to 30:1 (Zhang et al. 2008; Ponsá et al. 2011).

\section{Biohydrogen production by microbial fermentation}

Biohydrogen production from organic wastes is an eco-friendly approach for energy generation. Anaerobic digestion of OFMSW is one of the promising methods for hydrogen production. Hydrogen is a clean and renewable energy source and produces water as sole end product during combustion. It can be efficiently converted into electrical and thermal energy while being supplied to a fuel cell (Kumar et al. 2016; Sharma and Melkania 2017). The current technologies that produce biohydrogen from waste materials include biological fermentation (dark fermentation and photo fermentation), gasification, and microbial electrolysis cell. Dark fermentation (DF) is a process that involves microbial production of hydrogen under anaerobic and dark conditions. Hydrogen-producing microorganisms such as facultative and obligate anaerobes utilize carbohydrate-rich substrates and generate molecular hydrogen $\left(\mathrm{H}_{2}\right)$ by disposing the excess of electrons through hydrogenase enzyme activity. The protons $\left(\mathrm{H}^{+}\right)$act as electron accepters to neutralize electrons produced during the oxidation of organic compounds (Das and Veziroğlu 2001; Ghimire et al. 2015). Photo-fermentation (PF) is the biological process 
that needs light, which can be either solar or from an artificial source. PF produces hydrogen by the activity of photosynthetic bacteria, mainly purple non-sulfur bacteria. Simple sugars and different VFAs are the substrate for hydrogen production by photosynthetic bacteria. The degradation rate of different VFAs through photosynthetic bacteria is slower as compared to dark fermentation (Koku et al. 2002; Tian et al. 2019).

\section{OFMSW as substrate for hydrogen production}

As discussed in the previous section, an appropriate pretreatment of OFMSW is necessary for AD. Similarly, a suitable pretreatment is also required for efficient $\mathrm{H}_{2}$ through microbial fermentation using OFMSW as substrate. Several pretreatments such as physical, chemical, biological, and their combinations have been developed and tested for improved $\mathrm{H}_{2}$ production using OFMSW as substrate. Tawfik and Elsamadony (2015) crushed OFMSW to small particles and used the material for biohydrogen production using pilotscale dry anaerobic digester. Autoclaving is regarded as an ideal pretreatment method, as it shows several advantages over physiological methods. It does not require any chemical and is able to preserve the nutrients available in the organic wastes (Hu et al. 2014). Abubackar et al. (2019) carried out the pretreatment of fruit and vegetables wastes by autoclaving and studied $\mathrm{H}_{2}$ production by dry fermentation under thermophilic conditions. Fruit and vegetables wastes were treated in a 55-L reactor. The analysis showed a maximum $\mathrm{H}_{2}$ production $(41 \%$, v/v\%) with autoclaved fruits and vegetables wastes, while the hydrogen yield was $21 \%$ without autoclaving. In terms of total $\mathrm{H}_{2}$, approximately $30 \%$ higher production of $\mathrm{H}_{2}$ was achieved with autoclaving as compared to untreated fruit and vegetables wastes (Abubackar et al. 2019). OFMSW was used as substrate for coproduction of hydrogen and other byproducts such as butanol, ethanol, acetic acid, and butyric acid by Clostridium acetobutylicum NRRL B-591. The fermentation byproducts such as ethanol, acetic acid, and butyric acid were used for the pretreatment of OFMSW. The pretreatment was conducted with $85 \%$ ethanol and 0 to $1 \%(\mathrm{w} / \mathrm{w})$ acetic/butyric acid at 120 and $160{ }^{\circ} \mathrm{C}$ for $30 \mathrm{~min} .49 .8 \mathrm{~g} / \mathrm{L}$ of total reducing sugars were released by the pretreatment catalyzed by $1 \%$ acetic acid. During the fermentation process $114.1 \mathrm{~g}$ butanol, $43.8 \mathrm{~g}$ acetone, $15.1 \mathrm{~g}$ ethanol, $97.5 \mathrm{~L}$ of hydrogen were produced from one $\mathrm{kg}$ of OFMSW (Ebrahimian and Karimi 2020).

A mesophilic up-flow intermittently stirred tank reactor (UISTR) was used for hydrogen production from OFMSW. The UISTR was operated at five different hydraulic retention times (HRTs) of 10, 7.5, 5, 3, and 2 days. At HRT of 3 days and organic loading rate $(\mathrm{OLR})$ of $61.0 \mathrm{gCOD} / \mathrm{L} /$ day a maximum volumetric $\mathrm{H}_{2}$ production of $2.20 \pm 0.19 \mathrm{~L} / \mathrm{L} / \mathrm{d}$

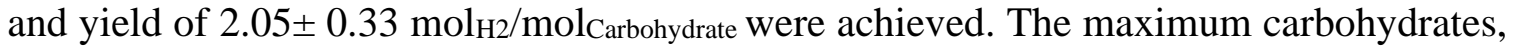
proteins, and lipids conversion was observed as 68.2 $\pm 13,37.5 \pm 6.7$, and $48.6 \pm 4.7 \%$, respectively, at HRT of 10 days and OLR of $18.1 \mathrm{gCOD} / \mathrm{L} /$ day (Elsamadony and Tawfik 2015). Biochar improved the $\mathrm{H}_{2}$ production from OFMSW by co-cultivation of Enterobacter aerogenes and E. coli. The addition of biochar facilitates the formation of biofilm and colonization of microorganisms on its large surface area. The maximum hydrogen yield of $96.63 \pm 2.8 \mathrm{~mL} \mathrm{H}_{2} / \mathrm{gCarbohydrate}$ initial and a maximum of $53.3 \pm 1 \% \mathrm{COD}$ removal were observed with the addition of $12.5 \mathrm{~g} / \mathrm{L}$ of biochar. The lag phase was shortened from $12.5 \pm 0.6 \mathrm{~h}$ to $8.1 \pm 0.5 \mathrm{~h}$ with the addition of biochar, and $\mathrm{H}_{2}$ production rates were also improved. When biochar was supplemented in addition to ammonia, the $\mathrm{H}_{2}$ production was increased, indicating that biochar can also mitigate inhibition caused by 
ammonia. Furthermore, the addition of biochar also improves the generation of VFAs (Sharma and Melkania 2017).

Biohydrogen production from OFMSW was enhanced by the addition of surfactant under dry anaerobic digestion. $\mathrm{H}_{2}$ production was performed under thermophilic conditions $\left(55^{\circ} \mathrm{C}\right)$ in batch fermentation. $\mathrm{H}_{2}$ production was significantly improved by the addition

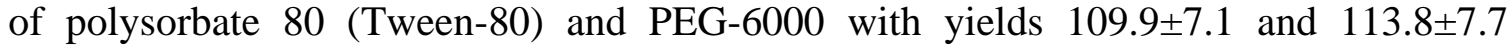
$\mathrm{mlH}_{2} / \mathrm{gCarb}$.initial, respectively. A combination of polysorbate80 (2.8\%) and PEG-6000 (1.7 $\mathrm{g} / \mathrm{L})$ resulted in a slightly higher yield of hydrogen $(116 \mathrm{mlH} / \mathrm{gCarb}$.initial $)$. This combination of surfactants resulted in the dominance of $\mathrm{H}_{2}$-producing bacteria such as Enterobacter, Escherichia, Buttiiauxella, and Pantoea (Elsamadony et al. 2015). Sharma and Melkania (2018) evaluated the effect of bioaugmentation with three bacterial species (E. coli, Bacillus subtilis, and Enterobacter aerogenes) on hydrogen production from OFMSW. Bioaugmentation with Bacillus subtilis resulted in the highest cumulative and volumetric hydrogen production of $564.4 \pm 10.9 \mathrm{~mL}$ and $1.61 \mathrm{LH}_{2} / \mathrm{L}_{\text {substrate, }}$, respectively, at a bacteria/sludge ratio of 0.25 . A highest cumulative hydrogen production of $486.3 \pm 10.6$ $\mathrm{mL}$ was observed by bioaugmentation with Enterobacter aerogenes at a bacteria/sludge ratio of 0.20 . Bioaugmentation with bacteria improved COD removal and VFAs generation, while the lag phase was shortened. The study concluded that the process of bioaugmentation with suitable bacteria may be a promising technique to improve the hydrogen yield (Sharma and Melkania 2018). Paillet et al. (2020) studied the effect of inorganic ions concentration of fermentative production of hydrogen from OFMSW. The composition of OFMSW in terms of organic compounds and inorganic ions is highly variable and it may affect the microbial activity during fermentation. A freshly created OFMSW was used to evaluate the effect of ionic concentration on hydrogen production at $\mathrm{pH} 6.0$ and temperature of $37^{\circ} \mathrm{C}$. At low concentrations of ammonium and chloride ions (2.9 to $5.1 \mathrm{gL}^{-1}$ ), a maximum yield of hydrogen $\left(40.8 \pm 0.5 \mathrm{mLH}_{2} . \mathrm{gVS}^{-1}, 25.1 \pm 5.6\right.$ $\mathrm{mLH} 2 . \mathrm{gVS}^{-1}$ respectively) was achieved. In contrast, the high ions concentrations strongly inhibited the microbial activity and hydrogen production. Ammonia, chloride, or a mixture of different ions caused a similar inhibitory effect regardless of the type of ion or the composition of ionic mixture. The inhibition was observed after a threshold value of ionic strength $(0.75 \pm 0.13 \mathrm{M})$ with a hydrogen yield of $18.1 \pm 3.3 \mathrm{mLH}^{2} . \mathrm{gVS}^{-1}$ to $6.2 \pm 4.1$ $\mathrm{mLH}_{2} . \mathrm{gVS}^{-1}$ at $0.81 \pm 0.12 \mathrm{M}$ (Paillet et al. 2020). The co-digestion of OFMSW and food waste (FW) was carried out for improved production of hydrogen under thermophilic anaerobic digestion with $20 \%$ total solids. OFMSW coming from a mechanical-biological treatment plant has a low organic content, and FW contains a high organic matter but creates problems during AD due to system acidification. Therefore, co-digestion of both using a ratio of 80:20 (OFMSW:FW) was performed to avoid above explained problems. The hydrogen production was improved by the addition of FW to OFMSW. Hydrogen productivity was increased from 0.64 to $2.5 \mathrm{H}_{2} /$ reactor day when SRT was decreased from 6.6 to 1.9 days. The hydrogen yield improved slightly from 33.7 to $38 \mathrm{~mL} \mathrm{H}_{2} / \mathrm{gVS}_{\text {added }}$ (Angeriz-Campoy et al. 2015).

\section{Energy production by microbial fuel cells}

Microbial fuel cells (MCFs) have received great attention in recent years as a bioelectrochemical for wastes conversion into electricity and hydrogen. In MCFs, microorganisms interact with electrodes and generate electricity through the metabolic activities of microorganisms. MCFs are considered to be a potential sustainable technology for energy generation using organic wastes and wastewaters (Pant et al. 2010). In MCFs, 
the exoelectrogenic microorganisms perform the degradation of organic biomass that generates the electrons. The free electrons are transferred from anode to cathode, thus generating electricity. A wide variety of monosaccharides can be used by exoelectrogenic microorganisms (Catal et al. 2019). OFMSW can be used as substrate for electricity and hydrogen generation by MFCs. El-Chakhtoura and coworkers (Catal et al. 2008) studied the electricity generation by air-cathode MFCs powdered with OFMSW. Two sets of aircathode MFCs were tested. In the first set, OFMSW was inoculated with cattle manure, which resulted in a maximum power density of $123 \pm 41 \mathrm{mWm}^{-2}$. In second the set, OFMSW was inoculated with wastewater sludge, giving a maximum power density of $116 \pm 29$ $\mathrm{mWm}^{-2}$. The COD removal was greater than $86 \%$ in all MFCs, and carbohydrates were removed by greater than $98 \%$. The $16 \mathrm{~S}$ rRNA sequencing showed the dominance of the phylum Firmicutes (67\%) on the anode, suggesting the possible role of members of this phylum in electricity generation (Catal et al. 2008). Tubular MFC in was used in fed-batch mode for electricity generation from OFMSW. The effect of temperature on the performance of reactor was tested by increasing the temperature with an interval of $5{ }^{\circ} \mathrm{C}$ in the range from 20 to $35{ }^{\circ} \mathrm{C}$. The maximum current density increased from 197.7 to 355.4 $\mathrm{mA} / \mathrm{m}^{2}$ after increment in the temperature. The power density production reached up to $47.6 \mathrm{mWm}^{2}$ from the initial value of $14.8 \mathrm{mWm}^{-2}$ at $100 \Omega$ external resistor. The analysis of $16 \mathrm{~S}$ rRNA sequences indicated the presence of Geobacter, which played an important role in transferring the electrons to the electrodes, and the Bacteroides and Clostridium contributed for fermentation (Karluvali et al. 2015). Chiu et al. carried out the electricity generation from OFMSW at different operational conditions. The two-chambered MFCs with carbon felt were used, and the carbon felt allocation showed a higher power density (20.12 and $30.47 \mathrm{mWm}^{-2}$ for 1.5 and $4 \mathrm{~L}$ respectively) as compared to other electrode plate allocations. Most two-chambered MFCs showed a higher maximal power density than single-chambered, with corresponding electrode plate allocations (Chiu et al. 2016).

Landfill leachate is a liquid that percolates through the landfill system. It is accumulated and manipulated to protect the environment. The landfill leachate may be a promising substrate for MFCs to generate electricity. Sonawane et al. (2017) utilized landfill leachate as feedstock for direct air-breathing-based MFCs for 17 days study under open circuit conditions. Three MFCs with different cathode area were taken, and the maximum open circuit voltage (OVC) of the cell was found to be $1.29 \mathrm{~V}$. The specific power density reached up to $1513 \mathrm{mWm}^{-2}$ with maximum cathode area (Sonawane et al. 2017). MSW landfill leachate treatment was performed by MFCs to generate the electricity in batch cycle without addition of inoculum. A maximum voltage of $635 \mathrm{mV}$ was produced using the larger-scale MCF. The operation over 52 days attained 74\%, 27\%, and 25\% removal of BOD, TOC and ammonia using the larger-scale MCF (Damiano et al. 2014).

\section{Comparison of Different Thermal and Biochemical WtE Technologies}

Incineration, pyrolysis, and gasification are widely used thermal processes for MSW conversion to energy that involve thermal breakdown in the form of heat or electricity. These thermal methods are differentiated by process conditions. Biochemical methods such as microbial fermentation, anaerobic digestion, and microbial fuel cells are environmentally friendly alternates for thermal processes. All of these methods have some advantages, limitations, and environmental impact. Table 7 shows a comparative analysis of thermal, landfill gas generation, and biochemical approaches. 
Table 7. Comparison of Different WtE Technologies

\begin{tabular}{|c|c|c|c|c|}
\hline WtE method & Advantages & Limitations & Products & $\begin{array}{l}\text { Environmental } \\
\text { impact }\end{array}$ \\
\hline Incineration & $\begin{array}{l}\text { - Reduces volume } \\
\text { and weight of waste } \\
\text { for landfilling }\end{array}$ & $\begin{array}{l}\text {-Heavy metals } \\
\text { management of } \\
\text { incinerated ash } \\
\text {-Extensive } \\
\text { infrastructure and } \\
\text { equipment required }\end{array}$ & $\begin{array}{l}\text { Heat, } \mathrm{CO}_{2}, \\
\mathrm{H}_{2} \mathrm{O} \text {, fly and } \\
\text { bottom ash, } \\
\text { gases }\end{array}$ & $\begin{array}{l}\text {-Air pollutants } \\
\text { including } \mathrm{SO}_{\mathrm{x}} \\
\mathrm{NO}_{\mathrm{x}}, \mathrm{Co}_{\mathrm{x}} \\
\text { polyaromatic } \\
\text { hydrocarbons } \\
\text {-Dioxin } \\
\text { emission from } \\
\text { fly ash }\end{array}$ \\
\hline Pyroly-sis & $\begin{array}{l}\text {-Generates lower } \\
\text { amount of } \\
\text { pollutants (dioxin, } \\
\text { nitrogen oxides and } \\
\text { sulphur oxides) as } \\
\text { compared to } \\
\text { incineration } \\
\text {-Emission control } \\
\text { strategies are } \\
\text { furnished with } \\
\text { pyrolysis facility }\end{array}$ & $\begin{array}{l}\text {-High viscosity of } \\
\text { pyrolysis oil may be } \\
\text { problematic for its } \\
\text { burning and } \\
\text { transportation } \\
\text {-Extensive } \\
\text { infrastructure and } \\
\text { equipment required }\end{array}$ & $\begin{array}{l}\text { Bio-oil, fuel } \\
\text { gas, char, } \\
\text { ash }\end{array}$ & $\begin{array}{l}\text {-Air pollutants } \\
\text { including } \mathrm{H}_{2} \mathrm{~S}, \\
\mathrm{NH}_{3}, \mathrm{SO}_{x}, \mathrm{NO}_{x} \text {, } \\
\text { and exhaust } \\
\text { gases }\end{array}$ \\
\hline Gasification & $\begin{array}{l}\text {-Reduced } \\
\text { generation of } \\
\text { pollutants (e.g. } \\
\text { dioxin \& furans) as } \\
\text { compared to } \\
\text { incineration, } \\
\text {-Gasification } \\
\text { produces syngas } \\
\text { that can be } \\
\text { combusted in } \\
\text { conventional burner } \\
\text { or gas engine }\end{array}$ & $\begin{array}{l}\text { - Extensive } \\
\text { infrastructure and } \\
\text { equipment required, } \\
\text { - Lack of local } \\
\text { knowledge in the } \\
\text { design, manufacture } \\
\text { and operation of } \\
\text { gasifiers as well as } \\
\text { the harzard and } \\
\text { safety issues of } \\
\text { gasifiers }\end{array}$ & $\begin{array}{l}\text { Syngas, tar, } \\
\text { hydrocarbons }\end{array}$ & $\begin{array}{l}\text {-Air pollutants } \\
\text { such as CO, } \\
\text { nitrogen and } \\
\text { sulphur oxides, } \\
\text { hydrocarbon, } \\
\text { dioxins, and } \\
\text { furans } \\
\text { generated, } \\
\text {-Waste water } \\
\text { and solid } \\
\text { residues } \\
\text { generated }\end{array}$ \\
\hline $\begin{array}{l}\text { Land- } \\
\text { filling }\end{array}$ & $\begin{array}{l}\text {-Cost effective and } \\
\text { less labor-intensive } \\
\text {-Landfill gas and } \\
\text { leachate collection } \\
\text { for energy } \\
\text { generation }\end{array}$ & $\begin{array}{l}\text {-High land } \\
\text { requirement } \\
\text {-If poorly managed, } \\
\text { they become niche } \\
\text { for scavengers, flies, } \\
\text { mosquitos, pests, } \\
\text { worms, rodents, and } \\
\text { pathogenic } \\
\text { microorganisms }\end{array}$ & $\begin{array}{l}\text {-Landfill gas } \\
\left(\mathrm{CH}_{4}, \mathrm{CO}_{2},\right. \\
\left.\mathrm{N}_{2}\right), \\
\text {-Leachate } \\
\text { (substrate for } \\
\text { AD and } \\
\text { MFCs) }\end{array}$ & $\begin{array}{l}\text {-Leachate is } \\
\text { generated that } \\
\text { contaminates } \\
\text { the soil and } \\
\text { ground water } \\
\text {-Generation of } \\
\text { contaminating } \\
\text { gases }\end{array}$ \\
\hline $\begin{array}{l}\text { Biochemical } \\
\text { methods (AD, } \\
\text { microbial } \\
\text { fermentations, } \\
\text { MFCs) }\end{array}$ & $\begin{array}{l}\text {-Can be performed } \\
\text { at small scale } \\
\text {-Compact design } \\
\text { needs less land } \\
\text { area } \\
\text {-Free from bad } \\
\text { odor, rodents fly, } \\
\text { and visible pollution }\end{array}$ & $\begin{array}{l}\text {-Not suitable for } \\
\text { wastes having lower } \\
\text { organic content } \\
\text {-Waste segregation } \\
\text { required for } \\
\text { improved efficiency }\end{array}$ & $\begin{array}{l}\text { Biogas\& } \\
\text { digestate, } \\
\text { biohydrogen, } \\
\text { and } \\
\text { bioelectricity }\end{array}$ & $\begin{array}{l}\text { Environmentally } \\
\text { friendly } \\
\text { processes } \\
\text {-Controls green } \\
\text { house gases } \\
\text { emissions }\end{array}$ \\
\hline
\end{tabular}

Sources: Arineitwe et al. 2013; Tozlu et al. 2016; Seo et al. 2018; Beyene et al. 2018; Nanda and Berruti 2020; Cudjoe et al. 2021 


\section{CONCLUSIONS}

Municipal solid waste (MSW) generation and consumption of energy is continuously increasing due to rapidly growing populations and increasing public living standards. The implementation of sustainable MSW management is the biggest issue around the world for the conservation of environment and human health. Recycling, the operation of landfills with gas recovery, thermal conversion processes, and biochemical conversion systems are the viable options for MSW handling and energy generation in the form of heat, electricity, bio-oil, syngas, biohydrogen, biogas, bioelectricity, etc. Thermal energy technologies are utilized for the waste reduction options with energy generation. Among the thermal conversion processes, pyrolysis has advantages over the conventional combustion due to less emission of air pollutants such as oxides of sulphur, nitrogen, and dioxin, etc. Biochemical methods are considered environmentally friendly and costeffective alternatives for energy generation from OFMSW. Biochemical process such as microbial fermentation for biohydrogen production, anaerobic digestion, and microbial fuel cell have gained wider acceptance in recent years. Some modifications such different pretreatments and particle size reduction of OFMSW have been tested to improve the efficiency of these methods. The biological efficiency of process can be improved by the selection of suitable pretreatment that depend on the type of substrate. Co-digestion of OFMSW and other nutrient-rich substrates is another strategy that improves the efficiency of anaerobic digestion. The recent research and developments have been focused on efficiency improvement of MFCs technology. In the future, the efficient MFCs technology can be coupled with landfilling that generates leachate. The leachate can be used as substrate for MFCs to generate biohydrogen and bioelectricity. WtE technologies are economically viable and environmentally sustainable alternate for energy recovery from MSW that is a widely available source of energy due to its continuous generation.

\section{CONFLICTS OF INTEREST}

The authors declare that there are no conflicts of interest regarding publication of this paper.

\section{REFERENCES CITED}

Abbasi, S. A. (2018). "The myth and the reality of energy recovery from municipal solid waste," Energy, Sustainability and Society 8(1), 36. DOI:10.1186/s13705-018-0175-y

ABRELPE. (2011). "Overview of solid waste in Brazil," Brazilian Association of Public Cleaning and Special Waste Companies, São Paulo.

Abubackar, H. N., Keskin, T., Yazgin, O., Gunay, B., Arslan, K., and Azbar, N. (2019).

"Biohydrogen production from autoclaved fruit and vegetable wastes by dry fermentation under thermophilic condition," International Journal of Hydrogen Energy 44(34), 18776-18784.

Abylkhani, B., Aiymbetov, B., Yagofarova, A., Tokmurzin, D., Venetis, C., Poulopoulos, S., Sarbassov, Y., and Inglezakis, V. J. (2019). "Seasonal characterisation of municipal solid waste from Astana city, Kazakhstan: Composition and thermal properties of combustible fraction," Waste Management \& Research 37(12), 1271-

Ram et al. (2021). "Municipal solid waste to energy," BioResources 16(2), 4275-4320. 
1281.

Adekunle, K. F., and Okolie, J. A. (2015). "A review of biochemical process of anaerobic digestion," Advances in Bioscience and Biotechnology 6(03), 205.

Ahmadian, M., Reshadat, S., Yousefi, N., Mirhossieni, S. H., Zare, M. R., Ghasemi, S. R., Gilan, N. R., Khamutian, R., Ahmadian, A., and Fatehizadeh, A. (2013). "Municipal leachate treatment by fenton process: Effect of some variable and kinetics," Pollutants Source Control and Health Effects 2013, 1-6.

Al Seadi, T., and Lukehurst, C. (2012). "Quality management of digestate from biogas plants used as fertiliser," IEA Bioenergy 37, 40.

Al., H. W., et al. (1997). "Biomass gasifiers for fuel cells systems," La Chimica e l'Industria. 79, 199-206.

Alam, P., and Ahmade, K. (2013). "Impact of solid waste on health and the environment," Special Issue of International Journal of Sustainable Development and Green Economics (IJSDGE), 2(1), 165-168.

Ali, S. A., and Ahmad, A. (2019). "Forecasting MSW generation using artificial neural network time series model: a study from metropolitan city," SN Applied Sciences, 1(11), 1338. DOI: 10.1007/s42452-019-1382-7

Ali, T. M. (2009). "Assessment of solid waste management system in Khartoum locality," Master thesis, 1-71.

Alibardi, L., and Cossu, R. (2015). "Composition variability of the organic fraction of municipal solid waste and effects on hydrogen and methane production potentials," Waste Management 36, 147-155. DOI: 10.1016/j.wasman.2014.11.019

Al-jaf, A. F., and Al-Ameen, J. I. (2019). "Modeling of municipal solid waste landfill gas generation: A case study, Kirkuk, Iraq," Journal of Materials and Environmental Sciences, 10(10), 987-994.

Al-Kaabi, S., Van Geel, P. J., and Warith, M. A. (2006). "Enhancement of the performance of the bioreactor landfills operating under saline condition by sludge addition."," in: Annual General Conf. of the Canadian Society for Civil Engineering, Canadian Society for Civil Engineering, Montreal, Canada, 1-9.

Allegue, L. D., Puyol, D., and Melero, J. A. (2020). "Novel approach for the treatment of the organic fraction of municipal solid waste: Coupling thermal hydrolysis with anaerobic digestion and photo-fermentation," Science of the Total Environment, 714, 136845.

Al-Salem, S. M., Antelava, A., Constantinou, A., Manos, G., and Dutta, A. (2017). “A review on thermal and catalytic pyrolysis of plastic solid waste (PSW)," Journal of Environmental Management 197, 177-198. DOI: 10.1016/j.jenvman.2017.03.084

Angelo, B. (2014). Lands of the Poor: Local Environmental Governance and the Decentralized Management of Natural Resources, UNDCF, New York, NY, USA,.

Angeriz-Campoy, R., Álvarez-Gallego, C. J., and Romero-García, L. I. (2015). "Thermophilic anaerobic co-digestion of organic fraction of municipal solid waste (OFMSW) with food waste (FW): Enhancement of bio-hydrogen production," Bioresource Technology 194, 291-296.

Anukam, A., Mohammadi, A., Naqvi, M., and Granström, K. (2019). "A review of the chemistry of anaerobic digestion: Methods of accelerating and optimizing process efficiency," Processes, Multidisciplinary Digital Publishing Institute, 7(8), 504.

Arena, U. (2012). "Process and technological aspects of municipal solid waste gasification. A review," Waste Management 32(4), 625-639. DOI: 10.1016/j.wasman.2011.09.025 
Arineitwe, J. N., Okure, M., Mutyaba, J., and Dinesh, S. (2013). "Prospects and limitations of biomass gasification for industrial thermal applications in Sub-Saharan Africa," in: Climate-Smart Technologies (pp. 435-445). Springer, Berlin, Heidelberg.

Ashik, M. A., Nazmul, M. H., and Rafizul, I. M. (2017). "Prediction of solid waste generation rate and determination of future waste characteristics at south-western region of Bangladesh using artificial neural network," in: WasteSafe 2017 Khulna (Bangladesh), 1-9.

ASTM. (1999). "Standard test method for determination of the composition of unprocessed municipal solid waste," D 5231-92, West Conshohocken, PA, USA.

AV., B. (1994). "Catalysis in thermal biomass conversion," Applied Catalysis A: General, 116, 5-47.

Ayeleru, O. O., Ntuli, F., and Mbohwa, C. (2016). "Utilization of Organic Fraction of Municipal Solid Waste (OFMSW) as compost: A case study of Florida, South Africa," in: World Congress on Engineering and Computer Science (WCECS), San Francisco, United States, 580-585.

Azam, M., Jahromy, S. S., Raza, W., Raza, N., Lee, S. S., Kim, K.-H., and Winter, F. (2020). "Status, characterization, and potential utilization of municipal solid waste as renewable energy source: Lahore case study in Pakistan," Environment International, 134, 105291. DOI: 10.1016/j.envint.2019.105291

Azman, S., Khadem, A. F., Van Lier, J. B., Zeeman, G., and Plugge, C. M. (2015). "Presence and role of anaerobic hydrolytic microbes in conversion of lignocellulosic biomass for biogas production," Critical Reviews in Environmental Science and Technology 45(23), 2523-2564.

Balat, M., and Balat, H. (2009). "Biogas as a renewable energy source - A review," Energy Sources , Part A Recovery, Utilization, and Environmental Effects 31, 12801293. DOI: $10.1080 / 15567030802089565$

Barbot, Y. N., Al-Ghaili, H., and Benz, R. (2016). "A review on the valorization of macroalgal wastes for biomethane production," Marine Drugs. DOI: $10.3390 / \mathrm{md} 14060120$

Bayuseno, A. P., and Schmahl, W. W. (2010). "Understanding the chemical and mineralogical properties of the inorganic portion of MSWI bottom ash," Waste Management 30(8), 1509-1520. DOI: 10.1016/j.wasman.2010.03.010

Bernardo, M., Lapa, N., Gonçalves, M., Barbosa, R., Mendes, B., Pinto, F., and Gulyurtlu, I. (2010). "Toxicity of char residues produced in the co-pyrolysis of different wastes," Waste Management 30(4), 628-635. DOI: 10.1016/j.wasman.2009.10.015

Beyene, H. D., Werkneh, A. A., and Ambaye, T. G. (2018). "Current updates on waste to energy (WtE) technologies: A review," Renewable Energy Focus 24, 1-11.

Beylot, A., Villeneuve, J., and Bellenfant, G. (2013). "Life cycle assessment of landfill biogas management: Sensitivity to diffuse and combustion air emissions," Waste Management 33(2), 401-411. DOI: 10.1016/j.wasman.2012.08.017

Bhoi, P. R., Huhnke, R. L., Kumar, A., Indrawan, N., and Thapa, S. (2018). "Cogasification of municipal solid waste and biomass in a commercial scale downdraft gasifier," Energy 163, 513-518. DOI: 10.1016/j.energy.2018.08.151

Blight, G. (2011). Landfills - Yesterday, Today and Tomorrow, Waste: A Handbook for Management, T. Letcher and D. Vallero (eds.), Academic Press.

Boone, D. R., Chynoweth, D. P., Mah, R. A., Smith, P. H., and Wilkie, A. C. (1993). "Ecology and microbiology of biogasification," Biomass and Bioenergy 5(3), 191- 
202. DOI: 10.1016/0961-9534(93)90070-K

Brown, D., and Li, Y. (2013). "Solid state anaerobic co-digestion of yard waste and food waste for biogas production," Bioresource Technology 127, 275-280. DOI: 10.1016/j.biortech.2012.09.081

Browne, J. D., and Murphy, J. D. (2013). "Assessment of the resource associated with biomethane from food waste," Applied Energy 104, 170-177. DOI:

10.1016/j.apenergy.2012.11.017

Bruce, N., Ng, K. T. W., and Richter, A. (2017). "Alternative carbon dioxide modelling approaches accounting for high residual gases in LandGEM," Environmental Science and Pollution Research 24(16), 14322-14336. DOI: 10.1007/s11356-017-8990-9

Campuzano, R., and González-Martínez, S. (2015). "Extraction of soluble substances from organic solid municipal waste to increase methane production," Bioresource Technology 178, 247-253.

Campuzano, R., and González-Martínez, S. (2016). "Characteristics of the organic fraction of municipal solid waste and methane production: A review," Waste Management 54, 3-12. DOI: 10.1016/j.wasman.2016.05.016

Catal, T., Li, K., Bermek, H., and Liu, H. (2008). "Electricity production from twelve monosaccharides using microbial fuel cells," Journal of Power Sources 175(1), 196200. DOI: 10.1016/j.jpowsour.2007.09.083

Catal, T., Liu, H., Fan, Y., and Bermek, H. (2019). "A clean technology to convert sucrose and lignocellulose in microbial electrochemical cells into electricity and hydrogen," Bioresource Technology Reports 5, 331-334.

Cesaro, A. and Belgiorno, V. (2014). "Pretreatment methods to improve anaerobic biodegradability of organic municipal solid waste fractions," Chemical Engineering Journal, 240, 24-37.

Chakraborty, M., Sharma, C., Pandey, J., and Gupta, P. K. (2013). “Assessment of energy generation potentials of MSW in Delhi under different technological options," Energy Conversion and Management 75, 249-255. DOI: 10.1016/j.enconman.2013.06.027

Chan, W. P., Veksha, A., Lei, J., Oh, W.-D., Dou, X., Giannis, A., Lisak, G., and Lim, T.-T. (2019). "A hot syngas purification system integrated with downdraft gasification of municipal solid waste," Applied Energy 237, 227-240. DOI: 10.1016/j.apenergy.2019.01.031

Chandler, A. J., Eighmy, T. T., Hartlén, J., Hjelmar, O., Kosson, D. S., Sawell, S. E., van der Sloot, H. A., and Vehlow, J. (1997). "Chapter 3 - Municipal solid waste incineration technologies," in: Municipal Solid Waste Incinerator Residues, A. J. Chandler, T. T. Eighmy, J. Hartlén, O. Hjelmar, D. S. Kosson, S. E. Sawell, H. A. van der Sloot, and J. Vehlow (eds.), Elsevier, pp. 59-95. DOI: 10.1016/S01661116(97)80009-X

Chang, C.-Y., Wang, C.-F., Mui, D. T., Cheng, M.-T., and Chiang, H.-L. (2009).

"Characteristics of elements in waste ashes from a solid waste incinerator in Taiwan," Journal of Hazardous Materials 165(1), 766-773. DOI:

10.1016/j.jhazmat.2008.10.059

Chaudhary, P. P., Brablcová, L., Buriánková, I., and Rulík, M. (2013). “Molecular diversity and tools for deciphering the methanogen community structure and diversity in freshwater sediments," Applied Microbiology and Biotechnology 97(17), 75537562. DOI: 10.1007/s00253-013-5102-8

Chen, C., Jin, Y., Yan, J., and Chi, Y. (2010). "Simulation of municipal solid waste gasification for syngas production in fixed bed reactors," Journal of Zhejiang 
University-SCIENCE A 11(8), 619-628. DOI: 10.1631/jzus.A0900792

Chen, D., Yin, L., Wang, H., and He, P. (2014). "Pyrolysis technologies for municipal solid waste: A review," Waste Management 34(12), 2466-2486. DOI:

10.1016/j.wasman.2014.08.004

Chen, Y., Cheng, J. J., and Creamer, K. S. (2008). "Inhibition of anaerobic digestion process: a review," Bioresource Technology99(10), 4044-4064.

Chiu, H. Y., Pai, T. Y., Liu, M. H., Chang, C. A., Lo, F. C., Chang, T. C., Lo, H. M., Chiang, C. F., Chao, K. P., and Lo, W. Y. (2016). "Electricity production from municipal solid waste using microbial fuel cells," Waste Management \& Research, SAGE Publications Sage UK: London, England, 34(7), 619-629.

Christensen, T. H., and Kjeldsen, P. (1989). "Basic biochemical process in landfills," in: Sanitary Landfilling: Process, Technology and Environmental Impact, Academic Press, San Diego, CA.

Chynoweth, D. P., Turick, C. E., Owens, J. M., Jerger, D. E., and Peck, M. W. (1993). "Biochemical methane potential of biomass and waste feedstocks," Biomass and Bioenergy 5(1), 95-111.

Cinquepalmi, M. A., Mangialardi, T., Panei, L., Paolini, A. E., and Piga, L. (2008). "Reuse of cement-solidified municipal incinerator fly ash in cement mortars: Physicomechanical and leaching characteristics," Journal of Hazardous Materials 151(2), 585-593. DOI: 10.1016/j.jhazmat.2007.06.026

Couto, N. D., Silva, V. B., and Rouboa, A. (2016). "Thermodynamic evaluation of Portuguese municipal solid waste gasification," Journal of Cleaner Production 139, 622-635. DOI: 10.1016/j.jclepro.2016.08.082

Cudjoe, D. and Acquah, P. M. (2021). "Environmental impact analysis of municipal solid waste incineration in African countries," Chemosphere, 265, 129186.

Damiano, L., Jambeck, J. R., and Ringelberg, D. B. (2014). "Municipal solid waste landfill leachate treatment and electricity production using microbial fuel cells," Applied Biochemistry and Biotechnology 173(2), 472-485.

Damtew, T., and Desta, N. (2015). "Micro and small enterprises in solid waste management : Experience of selected cities and towns in Ethiopia: A review," Pollution 1(4), 461-472.

Dangi, M. B., Pretz, C. R., Urynowicz, M. A., Gerow, K. G., and Reddy, J. M. (2011). "Municipal solid waste generation in Kathmandu, Nepal," Journal of Environmental Management 92(1), 240-249. DOI: 10.1016/j.jenvman.2010.09.005

Danish Energy Statistics. (2005). Danish Energy Authority. 9 January 2007, Archived from the original on 9 July 2012.

Das, D., and Veziroğlu, T. N. (2001). "Hydrogen production by biological processes: A survey of literature," International Journal of Hydrogen Energy 26(1), 13-28. DOI: 10.1016/S0360-3199(00)00058-6

de Souza, S. N. M., Horttanainen, M., Antonelli, J., Klaus, O., Lindino, C. A., and Nogueira, C. E. C. (2014). "Technical potential of electricity production from municipal solid waste disposed in the biggest cities in Brazil: Landfill gas, biogas and thermal treatment," Waste Management \& Research 32(10), 1015-1023. DOI: 10.1177/0734242X14552553

Della, R. C. (2001). I Processi e le Tecnologie di Gassificazione Delle Biomasse e dei Rifiuti Solidi, Universitadegli Studi di Salerno.

Dev, S. K., and Siddharth, J. (2020). "Municipal solid waste generation, composition, and management: The global scenario," Social Responsibility Journal. DOI: 
10.1108/SRJ-06-2019-0210

Ebrahimian, F., and Karimi, K. (2020). "Efficient biohydrogen and advanced biofuel coproduction from municipal solid waste through a clean process," Bioresource Technology 300, 122656.

Eddine, B. T., and Salah, M. M. (2012). "Solid waste as renewable source of energy: Current and future possibility in Algeria," International Journal of Energy and Environmental Engineering 3(1), 17. DOI: 10.1186/2251-6832-3-17

Elsamadony, M., and Tawfik, A. (2015). "Potential of biohydrogen production from organic fraction of municipal solid waste (OFMSW) using pilot-scale dry anaerobic reactor," Bioresource Technology 196, 9-16.

Elsamadony, M., Tawfik, A., and Suzuki, M. (2015). "Surfactant-enhanced biohydrogen production from organic fraction of municipal solid waste (OFMSW) via dry anaerobic digestion," Applied Energy 149, 272-282.

Erkut, E., Karagiannidis, A., Perkoulidis, G., and Tjandra, S. A. (2008). “A multicriteria facility location model for municipal solid waste management in North Greece," Eur. J. Operational Research 187, 1402.

Eurostat. (2009). "Municipal waste generation and treatment, by type of treatment method - kg per capita".

Fazeli, A., Bakhtvar, F., Leila, J., Sidik, N. A. C., and Bayat, A. E. (2016). "Malaysia's stand on municipal solid waste conversion to energy: A review," Renewable and Sustainable Energy Reviews 58, 1007-1016. DOI: 10.1016/j.rser.2015.12.270

Fernandes, R. P. R., Nogueira, M. de. A., and Jimenez, Í. (2018). "LandGEM model collection and use system for estimating the potential energy of biogas generated in landfills. Case study at the solid waste landfill of Manaus/Am," ITEGAM-J. Eng. Technol. Ind. Appl., 4.

Fernández-González, J. M., Grindlay, A. L., Serrano-Bernardo, F., Rodríguez-Rojas, M. I., and Zamorano, M. (2017). "Economic and environmental review of Waste-toEnergy systems for municipal solid waste management in medium and small municipalities," Waste Management, 67, 360-374. DOI: 10.1016/j.wasman.2017.05.003

Fernández-Rodríguez, J., Pérez, M., and Romero, L. I. (2013). "Comparison of mesophilic and thermophilic dry anaerobic digestion of OFMSW: Kinetic analysis," Chemical Engineering Journal 232, 59-64.

Ferraris, M., Salvo, M., Ventrella, A., Buzzi, L., and Veglia, M. (2009). "Use of vitrified MSWI bottom ashes for concrete production," Waste Management 29(3), 1041-1047. DOI: $10.1016 /$ j.wasman.2008.07.014

Ferreira, C., Ribeiro, A., and Ottosen, L. (2003). "Heavy metals in MSW incineration fly ashes," J. Phys. IV France, 107, 464-467.

Finnveden, G., Johansson, J., Lind, P., and Moberg, Å. (2005). "Life cycle assessment of energy from solid waste - Part 1: General methodology and results," Journal of Cleaner Production 13(3), 213-229. DOI: 10.1016/j.jclepro.2004.02.023

Forster-Carneiro, T., Pérez, M., and Romero, L. I. (2008). "Anaerobic digestion of municipal solid wastes: Dry thermophilic performance," Bioresource Technology 99(17), 8180-8184.

Forteza, R., Far, M., Seguí, C., and Cerdá, V. (2004). "Characterization of bottom ash in municipal solid waste incinerators for its use in road base," Waste Management 24(9), 899-909. DOI: 10.1016/j.wasman.2004.07.004

Fresca, F. R. C. (2007). "Analysis of municipal solid waste generation in São Carlos, SP, 
considering its physical characterization Master dissertation," University of São Paulo, São Carlos, SP, Brazil.

Fresh Energy (2013). "Is burning garbage green, in Sweden, there's little debate," 17 October 2013,Retrieved 31December 2020. https://energynews.us/2013/ 10/17/ midwest/is-burning-garbage-green-in-sweden-theres-little-debate/\#: :text= It $\% 20$ looks\%20like\%20dirty\%20business,capacity\%20over\%20the\%20past\%20decade.

Friedrich, E., and Trois, C. (2011). "Quantification of greenhouse gas emissions from waste management processes for municipalities - A comparative review focusing on Africa," Waste Management 31(7), 1585-1596. DOI: 10.1016/j.wasman.2011.02.028

Funari, V., Braga, R., Bokhari, S. N. H., Dinelli, E., and Meisel, T. (2015). "Solid residues from Italian municipal solid waste incinerators: A source for 'critical' raw materials," Waste Management 45, 206-216. DOI: 10.1016/j.wasman.2014.11.005

Garcia, J.-L. (1990). “Taxonomy and ecology of methanogens," FEMS Microbiology Letters 87(3-4), 297-308.

Garcia-Lodeiro, I., Carcelen-Taboada, V., Fernández-Jiménez, A., and Palomo, A. (2016). "Manufacture of hybrid cements with fly ash and bottom ash from a municipal solid waste incinerator," Construction and Building Materials 105, 218226. DOI: 10.1016/j.conbuildmat.2015.12.079

Gerardi, M. H. (2003). The Microbiology of Anaerobic Digesters, John Wiley \& Sons.

Ghasemzade, R., and Pazoki, M. (2017). "Estimation and modeling of gas emissions in municipal landfill (Case study: Landfill of Jiroft City)," Pollution 3(4), 689-700.

Ghimire, A., Frunzo, L., Pirozzi, F., Trably, E., Escudie, R., Lens, P. N. L., and Esposito, G. (2015). "A review on dark fermentative biohydrogen production from organic biomass: Process parameters and use of by-products," Applied Energy 144, 73-95.

$\mathrm{Gu}$, Q., Wu, W., Jin, B., and Zhou, Z. (2020). "Analyses for synthesis gas from municipal solid waste gasification under medium temperatures," Processes 8(1), 84-94.

Guendouz, J., Buffière, P., Cacho, J., Carrère, M., and Delgenes J. (2010). “Dry anaerobic digestion in batch mode: Design and operation of a laboratory-scale, completely mixed reactor," Waste Management 30, 1768-1771.

Gunaseelan, V. N. (1997). "Anaerobic digestion of biomass for methane production: A review," Biomass and Bioenergy 13(1-2), 83-114.

Gupta, V. K., Ali, I., Saini, V., Van Gerven, T., Van Bruggen, B. D., and Vandecasteele, C. (2005). "Removal of dyes from wastewater using bottom ash," Ind. Eng. Chem. Res. 44, 3655-3664.

Hartmann, H., and Ahring, B. K. (2006). "Strategies for the anaerobic digestion of the organic fraction of municipal solid waste: An overview," Water Science and Technology 53(8), 7-22.

Hartmann, H., Moller, H. B., and Ahring, B. K. (2004). "Efficiency of the anaerobic treatment of the organic fraction of municipal solid waste: Collection and pretreatment," Waste Management and Research 22, 35-41.

Hla, S. S., and Roberts, D. (2015). "Characterisation of chemical composition and energy content of green waste and municipal solid waste from Greater Brisbane, Australia," Waste Management 41, 12-19. DOI: 10.1016/j.wasman.2015.03.039

Hossain, M. S., Sivanesan, Y. S., Samir, S., and Mikolajczyk, L. (2014). "Effect of saline water on decomposition and landfill gas generation of municipal solid waste," Journal of Hazardous, Toxic, and Radioactive Waste18(2), 1-8. DOI: 10.1061/(ASCE)HZ.2153-5515.0000213

Hrabovsky, M., Konrad, M., Kopecky, V., Hlina, M., Kavka, T., Chumak, O., Van Oost, 
G., Beeckman, E., and Defoort, B. (2006). "Pyrolysis of wood in arc plasma for syngas production," High Temp. Mater. Processes (New York), 10, 557-570.

Hu, C. C., Giannis, A., Chen, C.-L., and Wang, J.-Y. (2014). "Evaluation of hydrogen producing cultures using pretreated food waste," International Journal of Hydrogen Energy 39(33), 19337-19342. DOI: 10.1016/j.ijhydene.2014.06.056

Hu, H., Luo, G., Liu, H., Qiao, Y., Xu, M., and Yao, H. (2013). "Fate of chromium during thermal treatment of municipal solid waste incineration (MSWI) fly ash," Proceedings of Combustion Institute 34, 2795-2801.

Huang, H., and Tang, L. (2007). "Treatment of organic waste using thermal plasma pyrolysis technology," Energy Conversation Management 48, 1331-1337.

Huang, Y., Chen, J., Shi, S., Li, B., Mo, J., and Tang, Q. (2020). "Mechanical properties of municipal solid waste incinerator (MSWI) bottom ash as alternatives of subgrade materials," Advances in Civil Engineering 202, article 9254516, 1-11.

Irfan, M., Li, A., Zhang, L., Wang, M., Chen, C., and Khushk, S. (2019). "Production of hydrogen enriched syngas from municipal solid waste gasification with waste marble powder as a catalyst," International Journal of Hydrogen Energy 44(16), 8051-8061. DOI: 10.1016/j.ijhydene.2019.02.048

Islam, K. M. N. (2016). "Municipal solid waste to energy generation in Bangladesh: Possible scenarios to generate renewable electricity in Dhaka and Chittagong City," Journal of Renewable Energy, (P. Purohit, ed.), Hindawi Publishing Corporation, 2016, 1-16. DOI: 10.1155/2016/1712370

Jain, P., Powell, J. T., Smith, J. L., Townsend, T. G., and Tolaymat, T. (2014). "Lifecycle inventory and impact evaluation of mining municipal solid waste landfills," Environmental Science \& Technology 48(5), 2920-2927. DOI: 10.1021/es404382s

Jain, S., Jain, S., Wolf, I. T., Lee, J., and Tong, Y. W. (2015). “A comprehensive review on operating parameters and different pretreatment methodologies for anaerobic digestion of municipal solid waste," Renewable and Sustainable Energy Reviews 52, 142-154.

Ji, H., Huang, W., Xing, Z., Zuo, J., Wang, Z., and Yang, K. (2019). “Experimental study on removing heavy metals from the municipal solid waste incineration fly ash with the modified electrokinetic remediation device," Scientific Reports 9(1), 8271. DOI: 10.1038/s41598-019-43844-w

John, N. M., Edem, S. O., Ndaeyo, N. U., and Ndon, B. A. (2006). "Physical composition of municipal solid waste and nutrient contents of its organic component in Uyo Municipality, Nigeria," Journal of Plant Nutrition 29(2), 189-194.

Juric, B., Hanzic, L., Ilic, R., and Samec, N. (2006). "Utilization of municipal solid waste bottom ash and recycled aggregate in concrete," Waste Management 26, 1436-1442.

Karak, T., Bhagat, R. M., and Bhattacharyya, P. (2012). "Municipal solid waste generation, composition, and management: The world scenario," Critical Reviews in Environmental Science and Technology 42, 1509-1630.

Karluvalı, A., Köroğlu, E. O., Manav, N., Çetinkaya, A. Y., and Özkaya, B. (2015). "Electricity generation from organic fraction of municipal solid wastes in tubular microbial fuel cell," Separation and Purification Technology 156, 502-511.

Katiyar, R. B., Suresh, S., and ASharma, A. K. (2013). "Characterisation of municipal solid waste generated by the city of Bhopal, India," International Journal of ChemTech Research 5(2), 623-628.

Kazuva, E., and Zhang, J. (2019). “Analyzing municipal solid waste treatment scenarios in rapidly urbanizing cities in developing countries: The Case of Dar es Salaam, 
Tanzania," International Journal of Environmental Research and Public Health 16(11), 2035. DOI: 10.3390/ijerph16112035

Khamis, S. S., Purwanto, H., Rozhan, A. N., Rahman, M. A., and Salleh, H. M. (2019). "Characterization of municipal solid waste in malaysia for energy recovery," in: IOP Conf. Series: Earth and Environmental Science, 1-6.

Kigozi, R., Aboyade, A., and Muzenda, E. (2014). "Biogas production using the organic fraction of municipal solid waste as feedstock," Int'l Journal of Research in Chemical, Metallurgical and Civil Engg 5(6), 107-114.

Kim, D., Prawisudha, P., and Yoshikawa, K. (2012). "Hydrothermal upgrading of Korean MSW for solid fuel production: Effect of MSW composition," Journal of Combustion 2012, 781659. DOI: 10.1155/2012/781659

Klein, A. (2002). Gasification: An Alternative Process for Energy Recovery and Disposal of Municipal Solid Wastes, Ph D. thesis, Columbia University, New York.

Kleis, H., and Dalagar, S. (2007). 100 Years of Waste Incineration in Denmark - From Refuse Destruction Plants to High-technology Energy Works, Babcock \& Wilcox Vølund.

Klinghoffer, N. B., and Castaldi, M. J. (2013). "9 - Gasification and pyrolysis of municipal solid waste (MSW)," in: Woodhead Publishing Series in Energy, N. B. Klinghoffer and M. J. B. T.-W. to E. C. T. Castaldi, (eds.), Woodhead Publishing, pp. 146-176. DOI: 10.1533/9780857096364.2.146

Koido, K., and Iwasaki, T. (2017). "Biomass gasification: A review of its technology, gas cleaning applications, and total system life cycle analysis," in: Lignin-Trends and Applications, M. Poletto(ed.), IntechOpen, 161-180.

Koku, H., Eroğlu, İ., Gündüz, U., Yücel, M., and Türker, L. (2002). “Aspects of the metabolism of hydrogen production by Rhodobacter sphaeroides," International Journal of Hydrogen Energy 27(11), 1315-1329. DOI: 10.1016/S03603199(02)00127-1

Korai, M. S., Mahar, R. B., and Uqaili, M. A. (2016). "Optimization of waste to energy routes through biochemical and thermochemical treatment options of municipal solid waste in Hyderabad, Pakistan," Energy Conversion and Management 124, 333-343. DOI: 10.1016/j.enconman.2016.07.032

Kumar, A., Aggarwal, D., Yadav, M., Kumar, P., and Kumar, V. (2019). "Biotechnological conversion of plant biomass into value-added products," in: Industrial Biotechnology, M. Yadav, V. Kumar, and N. Sehrawat (eds.), De Gruyter, pp. 51-72. DOI: 10.1515/9783110563337-003

Kumar, A., Gautam, A., and Dutt, D. (2016). "Biotechnological transformation of lignocellulosic biomass in to industrial products: An overview," Advances in Bioscience and Biotechnology 07(03), 149-168. DOI: 10.4236/abb.2016.73014

Lam, C. H. K., Ip, A. W. M., Barford, J. P., and Mckay, G. (2010). "Use of incineration MSW ash: A review," Sustainability 2, 1943-1968.

Leone, S., Sankoh, F. P., Yan, X., and Tran, Q. (2013). "Environmental and health impact of solid waste disposal in developing cities: A case study of granville brook dumpsite, Freetown, Sierra Leone," Journal of Environmental Protection 4, 665-670.

Li, S. Q., Li, A. M., Yan, J. H., and Ren, Y. (2000). "Pyrolysis of the biomass wastes pyrolysis in a rotary kiln: Influences of reaction conditions on pyrolysis product distribution," Acta Energiae Solaris Sinica (in Chinese), 21, 333-339.

Li, X. Y., Zhang, Y. F., Niu, B. L., and Wang, Y. (2007). "Studying on pyrolysis furnace and pyrolysis characteristics of solid wastes," J. Huazhong Univ. Sci. Technol. 
Science) 35, 99-102 (in Chinese).

Liu, J., Chen, J., and Huang, L. (2015). "Heavy metal removal from MSS fly ash by thermal and chlorination treatments," Scientific Reports 5 (1), 1-15

Lo, Y.-C., Saratale, G. D., Chen, W.-M., Bai, M.-D., and Chang, J.-S. (2009). "Isolation of cellulose-hydrolytic bacteria and applications of the cellulolytic enzymes for cellulosic biohydrogen production," Enzyme and Microbial Technology 44(6), 417425. DOI: 10.1016/j.enzmictec.2009.03.002

Lou, X. F., and Nair, J. (2009). "The impact of landfilling and composting on greenhouse gas emissions - A review," Bioresource Technology 100(16), 3792-3798. DOI: 10.1016/j.biortech.2008.12.006

Lu, L.-T., Hsiao, T.-Y., Shang, N.-C., Yu, Y.-H., and Ma, H.-W. (2006). "MSW management for waste minimization in Taiwan: The last two decades," Waste Management 26(6), 661-667. DOI: 10.1016/j.wasman.2005.10.005

Macquarrie, D. J., Clark, J. H., and Fitzpatrick, E. (2012). "The microwave pyrolysis of biomass," Biofuels, Bioprod. Biorefinery 6, 55-66.

Makarichi, L., Kan, R., Jutidamrongphan, W., and Techato, K. (2019). "Suitability of municipal solid waste in African cities for thermochemical waste-to-energy conversion: The case of Harare Metropolitan City, Zimbabwe," Waste Management \& Research 37(1), 83-94.

Makauki, E., King'ondu, C. K., and Kibona, T. E. (2017). "Hydrogen sulfide and ammonia removal from biogas using water hyacinth-derived carbon nanomaterials," African Journal of Environmental Science and Technology (Academic Journals) 11(7), 375-383.

Malkow, T. (2004). "Novel and innovative pyrolysis and gasification technologies for energy efficient and environmentally sound MSW disposal," Waste Management 24(1), 53-79. DOI: 10.1016/S0956-053X(03)00038-2

Marie, M., and Peter, M. (2011). "Optimization of use of waste in the future energy system,” Energy 36(3), 1612-1622.

Martin, J. H., Collins, A. R., Robert, P. E., and Diener, G. (1995). "A sampling protocol for composting, recycling, and re-use of municipal solid waste," Journal of the Air \& Waste Management Association 45(11), 864-870.

Martínez, I., Grasa, G., Callén, M. S., López, J. M., and Murillo, R. (2020). “Optimised production of tailored syngas from municipal solid waste (MSW) by sorptionenhanced gasification," Chemical Engineering Journal 401, 126067. DOI: 10.1016/j.cej.2020.126067

Materazzi, M., and Taylor, R. (2019). "Plasma-assisted gasification for waste-to-fuels applications," Industrial \& Engineering Chemistry Research 58(35), 15902-15913. DOI: 10.1021/acs.iecr.9b01239

Matsakas, L., Gao, Q., Jansson, S., Rova, U., and Christakopoulos, P. (2017). "Green conversion of municipal solid wastes into fuels and chemicals," Electronic Journal of Biotechnology 26, 69-83. DOI: 10.1016/j.ejbt.2017.01.004

Mayer, F., Gerin, P. A., Noo, A., Foucart, G., Flammang, J., Lemaigre, S., Sinnaeve, G., Dardenne, P., and Delfosse, P. (2014). "Assessment of factors influencing the biomethane yield of maize silages," Bioresource Technology 153, 260-268. DOI: 10.1016/j.biortech.2013.11.081

Melts, I., Normak, A., Nurk, L., and Heinsoo, K. (2014). "Chemical characteristics of biomass from nature conservation management for methane production," Bioresource Technology 167, 226-231. DOI: 10.1016/j.biortech.2014.06.009 
Memon, M. A. (2010). "Integrated solid waste management based on the 3R approach," Journal of Material Cycles and Waste Management 12(1), 30-40.

Menikpura, S. N. M., Basnayake, B. F. A., Boyagoda, P. B., and Kularathne, I. W. (2007). "Estimations and mathematical model predictions of energy contents of municipal solid waste (MSW) in Kandy," Tropical Agricultural Research 19, 389400.

Miezah, K., Obiri-danso, K., Kádár, Z., Fei-baffoe, B., and Mensah, M. Y. (2015). "Municipal solid waste characterization and quantification as a measure towards effective waste management in Ghana," Waste Management 46, 15-27. DOI: 10.1016/j.wasman.2015.09.009

Miskolczi, N., Ateş, F., and Borsodi, N. (2013). "Comparison of real waste (MSW and MPW) pyrolysis in batch reactor over different catalysts. Part II: Contaminants, char and pyrolysis oil properties," Bioresource Technology 144, 370-379. DOI: 10.1016/j.biortech.2013.06.109

Molino, A., Nanna, F., Ding, Y., Bikson, B., and Braccio, G. (2013). "Biomethane production by anaerobic digestion of organic waste," Fuel 103, 1003-1009.

Monavari, S. M., Omrani, G. A., Karbassi, A., and Raof, F. F. (2012). "The effects of socioeconomic parameters on household solid-waste generation and composition in developing countries (a case study: Ahvaz, Iran)," Environmental Monitoring and Assessment 184(4), 1841-1846. DOI: 10.1007/s10661-011-2082-y

Moreno, A. D., Rodriguez, M. G., Velasco, A. R., Enriquez, J. C. M., Lara, R. G., Gutierrez, A. M., and Hernández, N. A. D. (2013). "Mexico city’s municipal solid waste characteristics and composition analysis," Rev. Int. Contam. Ambie. 29(1), 3946.

Nanda, S. and Berruti, F. (2020) "Municipal solid waste management and landfilling technologies: A review," Environmental Chemistry Letters DOI: 10.1007/s10311020-01100-y

Ngusale, G. K., Oloko, M., Agong, S., and Nyakinya, B. (2017). "Energy recovery from municipal solid waste," Energy Sources, Part A: Recovery, Utilization, and Environmental Effects 39(16), 1807-1814. DOI: 10.1080/15567036.2017.1376007

Njoku, P. O., Odiyo, J. O., Durowoju, O. S., and Edokpayi, J. N. (2018). "A review of landfill gas generation and utilisation in Africa," Open Environmental Sciences 10, 115.

Nzila, A. (2017). "Mini review: Update on bioaugmentation in anaerobic processes for biogas production," Anaerobe 46, 3-12. DOI: 10.1016/j.anaerobe.2016.11.007

Olisa, Y. P., and Ajoko, T. J. (2018). "Gross calorific value of combustible solid waste in a mass burn incineration plant, Benin City, Nigeria," J. Appl. Sci. Environ. Manage. 22, 1377-1380.

Ozcan, H. K., Guvenc, S. Y., Guvenc, L., and Demir, G. (2016). "Municipal solid waste characterization according to different income levels: A case study," Sustainability 8, 1044-1055.

Paillet, F., Barrau, C., Escudié, R., and Trably, E. (2020). "Inhibition by the ionic strength of hydrogen production from the organic fraction of municipal solid waste," International Journal of Hydrogen Energy 45(10), 5854-5863.

Paisley, M. A., and Anson, D. (1998). "Biomass gasification for gas turbine-based power generation," Transactions-American Society of Mechanical Engineers Journal of Engineering for Gas Turbines And Power 120, 284-288.

Palacio, C. E. (2019). "Municipal solid waste management and energy recovery,"in: 
Energy Conversion - Current Technologies and Future Trends, I. H. Bahadly (ed.), Intech Open.

Palmisano, A. C., and Barlaz, M. A. (1996). Microbiology of Solid Waste, CRC press.

Pan, A., Yu, L., and Yang, Q. (2019). "Characteristics and forecasting of municipal solid waste generation in China," Sustainability. DOI: 10.3390/su11051433

Pan, J. R., Huang, C., Kuo, J.-J., and Lin, S.-H. (2008). "Recycling MSWI bottom and fly ash as raw materials for Portland cement," Waste Management 28(7), 1113-1118. DOI: 10.1016/j.wasman.2007.04.009

Pant, D., Van Bogaert, G., Diels, L., and Vanbroekhoven, K. (2010). "A review of the substrates used in microbial fuel cells (MFCs) for sustainable energy production," Bioresource Technology 101(6), 1533-1543.

Paritosh, K., Yadav, M., Mathur, S., Balan, V., Liao, W., Pareek, N., and Vivekanand, V. (2018). "Organic fraction of municipal solid waste: Overview of treatment methodologies to enhance anaerobic biodegradability," Frontiers in Energy Research, 6, 75.

Park, Y. J., and Heo, J. (2002). "Conversion to glass-ceramics from glasses made by MSW incinerator fly ash for recycling," Ceramics International 28(6), 689-694. DOI: 10.1016/S0272-8842(02)00030-5

Ponsá, S., Gea, T., and Sánchez, A. (2011). "Anaerobic co-digestion of the organic fraction of municipal solid waste with several pure organic co-substrates," Biosystems Engineering 108(4), 352-360.

Qdais, H. A. A., Hamoda, M. F., and Newham, J. (1997). “Analysis of residential solid waste at generation sites," Waste Management \& Research 15(4), 395-406. DOI: 10.1006/wmre.1996.0095

Qin, Y., Bai, Y., Shen, Z., and Zhang, K. (2008). "Design of combustion control system for MSW incineration plant," in: 2008 International Conference on Intelligent Computation Technology and Automation (ICICTA), pp. 341-344. DOI: 10.1109/ICICTA.2008.309

Quek, A., Xu, W., Guo, L. and Wu, D. (2020). "Heavy metal removal from incineration bottom ash through washing with rainwater and seawater," International Journal of Waste Resources 2016, 6:1.

Quina, M. J., Bontempi, E., Bogush, A., Schlumberger, S., Weibel, G., Braga, R., Funari, V., Hyks, J., Rasmussen, E., and Lederer, J. (2018). "Technologies for the management of MSW incineration ashes from gas cleaning: New perspectives on recovery of secondary raw materials and circular economy," Science of the Total Environment 635, 526-542. DOI: 10.1016/j.scitotenv.2018.04.150

Rezaee, R., Nasseri, S., Mahvi, A. H., and Jafari, A. (2014). "Estimation of gas emission released from a municipal solid waste landfill site through a modeling approach: A case study, Sanandaj, Iran," Journal of Advances in Environmental Health Research 2(1), 13-21.

Riber, C. (2006). Waste to Energy in Denmark, Ramboll Group A/S, Copenhagen, Denmark.

Rotich, K. H., Zhao, Y., and Dong, J. (2006). "Municipal solid waste management challenges in developing countries - Kenyan case study," Waste Management 26(1), 92-100.

Rughoonundun, H., Mohee, R., and Holtzapple, M. T. (2012). "Influence of carbon-tonitrogen ratio on the mixed-acid fermentation of wastewater sludge and pretreated bagasse," Bioresource Technology 112, 91-97. DOI: 10.1016/j.biortech.2012.02.081 
Scarlat, N., Motola, V., Dallemand, J. F., Monforti-Ferrario, F., and Mofor, L. (2015). "Evaluation of energy potential of municipal solid waste from African urban areas," Renewable Sustainable Energy Reviews 50, 1269-1286.

Seo, Y.-C., Alam, M. T., and Yang, W.-S. (2018). "Gasification of municipal solid waste (Chapter 7)," in: Gasification for Low-grade Feedstock, Yongseung Yun, IntechOpen USA, 115-141.

Seruga, P., Krzywonos, M., Seruga, A., Niedźwiecki, Ł., Pawlak-Kruczek, H., and Urbanowska, A. (2020). "Anaerobic digestion performance: Separate collected vs. mechanical segregated organic fractions of municipal solid waste as feedstock," Energies 13(15), 3768.

Sharma, P., and Melkania, U. (2017). "Biochar-enhanced hydrogen production from organic fraction of municipal solid waste using co-culture of Enterobacter aerogenes and E. coli," International Journal of Hydrogen Energy 42(30), 18865-18874. DOI: 10.1016/j.ijhydene.2017.06.171

Sharma, P., and Melkania, U. (2018). "Effect of bioaugmentation on hydrogen production from organic fraction of municipal solid waste," International Journal of Hydrogen Energy 43(15), 7290-7298.

Shekdar, A. V. (2009). "Sustainable solid waste management: An integrated approach for Asian countries," Waste Management 29(4), 1438-1448. DOI: 10.1016/j.wasman.2008.08.025

Siddiqi, M. M., Naseer, M. N., Abdul Wahab, Y., Hamizi, N. A., Badruddin, I. A., Chowdhury, Z. Z., Akbarzadeh, O., Johan, M. R., Khan, T. M. Y., and Kamangar, S. (2019). "Evaluation of municipal solid wastes based energy potential in urban Pakistan," Processes 7, 848-860.

Singh, M., and Leena, G. (2020). "Waste to energy -World scenario: A review," in: Sustainable Waste Management: Policies and Case Studies., Ghosh S. (ed.), Springer, Singapore, pp. 267-278.

Singh, R. P., Tyagi, V. V., Allen, T., Ibrahim, M. H., and Kothari, R. (2011). “An overview for exploring the possibilities of energy generation from municipal solid waste (MSW) in Indian scenario," Renewable and Sustainable Energy Reviews 15(9), 4797-4808. DOI: 10.1016/j.rser.2011.07.071

Sonawane, J. M., Adeloju, S. B., and Ghosh, P. C. (2017). "Landfill leachate: A promising substrate for microbial fuel cells," International Journal of Hydrogen Energy 42(37), 23794-23798.

Srivastava, A. N., and Chakma, S. (2020). "Quantification of landfill gas generation and energy recovery estimation from the municipal solid waste landfill sites of Delhi, India," Energy Sources, Part A: Recovery, Utilization, and Environmental Effects 42, 1-14. DOI: 10.1080/15567036.2020.1754970

Staley, B. F., and Barlaz, M. A. (2009). "Composition of municipal solid waste in the united states and implications for carbon sequestration and methane yield," Journal of Environmental Engineering 135(10), 901-909.

Swedish Institute "The swedish recycling revolution." (2015). Retrieved 31December, 2020.https://sweden.se/nature/the-swedish-recycling-revolution/\#

Taiwan Environmental Protection Agency. (2004). "The research on the utilization of MSWI residues (II): Taipei, Taiwan".

Tan, S. T., Hashim, H., Lee, C. T., Lim, J. S., and Kanniah, K. D. (2014). 'Optimal waste-to-energy strategy assisted by GIS For sustainable solid waste management," in: IOP Conference Series: Earth and Environmental Science, Volume 18, 8th 
International Symposium of the Digital Earth (ISDE8), Kuching, Sarawak, Malaysia. Tańczuk, M., Junga, R., Werle, S., Chabiński, M., and Ziółkowski, Ł. (2019).

"Experimental analysis of the fixed bed gasification process of the mixtures of the chicken manure with biomass," Renewable Energy 136, 1055-1063. DOI: 10.1016/j.renene.2017.05.074

Tang, Q. Gu, F., Chen, H., Lu, C. and Zhang, Y. (2018). "Mechanical evaluation of bottom ash from municipal solid waste incineration used in roadbase," Advances in Civil Engineering, vol. 2018, Article ID 5694908, 1-8.

Tang, Q., Liu, Y., Gu, F., and Zhou, T. (2016).“Solidification/stabilization of fly ash from a municipal solid waste incineration facility using portland cement," Advances in Materials Science and Engineering 2016, Article ID 7101243.

Tanigaki, N., Manako, K., and Osada, M. (2012). "Co-gasification of municipal solid waste and material recovery in a large-scale gasification and melting system," Waste Management 32(4), 667-675. DOI: 10.1016/j.wasman.2011.10.019

Tanoh, T. S., Ait Oumeziane, A., Lemonon, J., Escudero Sanz, F. J., and Salvador, S. (2020). "Green waste/wood pellet pyrolysis in a pilot-scale rotary kiln: Effect of temperature on product distribution and characteristics," Energy \& Fuels 34(3), 33363345. DOI: 10.1021/acs.energyfuels.9b04365

Theuerl, S., Klang, J., and Prochnow, A. (2019). "Process disturbances in agricultural biogas production-Causes, mechanisms and effects on the biogas microbiome: A review," Energies, Multidisciplinary Digital Publishing Institute, 12(3), 365.

Tian, H., Li, J., Yan, M., Tong, Y. W., Wang, C.-H., and Wang, X. (2019). “Organic waste to biohydrogen: A critical review from technological development and environmental impact analysis perspective," Applied Energy 256, 113961.

Tozlu, A., Özahi, E., and Abuşoğlu, A. (2016). "Waste to energy technologies for municipal solid waste management in Gaziantep," Renewable and Sustainable Energy Reviews 54, 809-815.

Trehrani, F. B., and Haghi, E. (2015). "Techno-economic assessment of municipal solid waste incineration plant-case study of Tehran, Iran," in: The First Sustainable Development conference of Engineering Systems in Energy, water and Environment, Iran University of Science and Technology, Tehran, Iran, Tehran, Iran, pp. 1-4.

U.S. Energy Information Administration. (2019). "Biomass explained Landfill gas and biogas, Last updated: November 12, 2019."

U.S. Envrionmental Protection Agency. (2020). "Basic Information about Landfill Gas: Landfill Methane Outreach Program (LMOP)."

United Nations. (2019). Department of Economic and Social Affairs, Population Division. World Population Prospects 2019: Highlights (ST/ESA/SER.A/423).

US EIA. (2019). USEPA, "Advancing sustainable materials management fact sheet" (Updated in November 2019).

USEPA. (2014). "Municipal solid waste generation, recycling, and disposal in the United States (Tables and Figures for 2012)," Office of Resource Conservation and Recovery.

Uz Zaman, A. (2009). "Technical development of waste sector in Sweden: Survey and life cycle environmental assessment of emerging technologies," Kungliga Tekniska Högskolan.

Vaish, B., Srivastava, V., Singh, P., Singh, A., Singh, P. K., and Singh, R. P. (2016). "Exploring untapped energy potential of urban solid waste," Energy, Ecology and Environment 1(5), 323-342. DOI: 10.1007/s40974-016-0023-x 
Vandevivere, P., De Baere, L., and Verstraete, W. (2003). "Types of anaerobic digester for solid wastes," in: Biomethanization of the Organic Fraction of Municipal Solid Wastes, Iwa Publishing, pp. 111-140.

Vegas, I., Ibañez, J. A., San José, J. T., and Urzelai, A. (2008). "Construction demolition wastes, Waelz slag and MSWI bottom ash: A comparative technical analysis as material for road construction," Waste Management 28(3), 565-574. DOI: 10.1016/j.wasman.2007.01.016

Wang, H., Lehtomäki, A., Tolvanen, K., Puhakka, J., and Rintala, J. (2009). "Impact of crop species on bacterial community structure during anaerobic co-digestion of crops and cow manure," Bioresource Technology 100(7), 2311-2315. DOI:

10.1016/j.biortech.2008.10.040

Wang, L., Shen, F., Yuan, H., Zou, D., Liu, Y., Zhu, B., and Li, X. (2014). “Anaerobic co-digestion of kitchen waste and fruit / vegetable waste: Lab-scale and pilot-scale studies," Waste Management 34(12), 2627-2633. DOI:

10.1016/j.wasman.2014.08.005

Wang, P., Hu, Y., and Cheng, H. (2019). "Municipal solid waste (MSW) incineration fly ash as an important source of heavy metal pollution in China," Environmental Pollution 252(Part A), 461-475. DOI: 10.1016/j.envpol.2019.04.082

Wang, P., Wang, H., Qiu, Y., Ren, L., and Jiang, B. (2018). "Microbial characteristics in anaerobic digestion process of food waste for methane production-A review," Bioresource Technology 248, 29-36.

Wang, T. (2018). "Generation of municipal solid waste worldwide in 2017," Retrieved 31 December, 2020. https://www.statista.com/statistics/916749/global-generation-ofmunicipal-solid-waste-by-country/

Wang, T. (2019). "Global population and MSW generation share by key country in 2018," Retrieved 31 December, 2020. https://www.statista.com/statistics/1026652/population-share-msw-generation-byselect-country/

Wang, Y., Ng, K. T. W., and Asha, A. Z. (2016). "Non-hazardous waste generation characteristics and recycling practices in Saskatchewan and Manitoba, Canada," Journal of Material Cycles and Waste Management 18(4), 715-724. DOI: 10.1007/s10163-015-0373-z

Wang, Z. M., and Huang, S. S. (2008). "Novel $300 \mathrm{~kW}$ arc plasma inverter system based on hierarchical controlled building block structure," China Welding (English Edition), 7, 12-16.

Wangyao, K., Yamada, M., Endo,K., Ishigaki, T., Naruoka, T., Towprayoon, S., Chiemchaisri, C., and Sutthasil, N. (2010). "Methane generation rate constant in tropical landfill," Journal of Sustainable Energy \& Environment 1, 181-184.

Weber, B., and Stadlbauer, E. A. (2017). "Sustainable paths for managing solid and liquid waste from distilleries and breweries," Journal of Cleaner Production 149, 3848. DOI: 10.1016/j.jclepro.2017.02.054

Wei, Y., Shimaoka, T., Saffarzadeh, A., and Takahashi, F. (2011). "Mineralogical characterization of municipal solid waste incineration bottom ash with an emphasis on heavy metal-bearing phases," Journal of Hazardous Materials 187(1), 534-543. DOI: 10.1016/j.jhazmat.2011.01.070

Westerholm, M., and Schnürer, A. (2019). "Microbial responses to different operating practices for biogas production systems," in: Anaerobic Digestion, IntechOpen, 1-36. Wong, S., Mah, A. X. Y., Nordin, A. H., Nyakuma, B. B., Ngadi, N., Mat, R., Amin, N. 
A. S., Ho, W. S., and Lee, T. H. (2020). "Emerging trends in municipal solid waste incineration ashes research: a bibliometric analysis from 1994 to 2018," Environmental Science and Pollution Research 27(8), 7757-7784. DOI: 10.1007/s11356-020-07933-y

World Bank. (2012). (Hoornweg, D., and Bhada-Tata, P.). "What a waste, A global review of solid waste management," World Bank report, No. 15.

World Bank. (2019). Solid Waste Management.

World Energy Council. (2013). World Energy Resources: A Summary, Regency House 14 Warwick Street London W1B 5LT United Kingdom.

Wu, B., Wang, D., Chai, X., Takahashi, F., and Shimaoka, T. (2016). "Characterization of chlorine and heavy metals for the potential recycling of bottom ash from municipal solid waste incinerators as cement additives," Frontiers of Environmental Science \& Engineering 10(4), 8. DOI: 10.1007/s11783-016-0847-9

Wu, H., Cheng, X., Zhu, Y., Zeng, W., Chen, G., and Liang, Z. (2018). "Purification and characterization of a cellulase-free, thermostable endo-xylanase from Streptomyces griseorubens LH-3 and its use in biobleaching on eucalyptus kraft pulp," Journal of Bioscience and Bioengineering 125(1), 46-51. DOI: 10.1016/j.jbiosc.2017.08.006

Wu, H.-Y., and Ting, Y.-P. (2006). "Metal extraction from municipal solid waste (MSW) incinerator fly ash-Chemical leaching and fungal bioleaching," Enzyme and Microbial Technology 38(6), 839-847. DOI: 10.1016/j.enzmictec.2005.08.012

Xue, Y., Kelkar, A., and Bai, X. (2016). "Catalytic co-pyrolysis of biomass and polyethylene in a tandem micropyrolyzer," Fuel 166, 227-236. DOI:

10.1016/j.fuel.2015.10.125

Yearbook. (2017). "China urban and rural construction statistical."

Yusuff, A. S., John, W., Okoro, O., and Ajibade, A. (2014). "Physico-chemical composition and energy content analysis of solid waste: A case study of Castlereagh district, Northern Ireland," American Journal of Engineering Science and Technology Research 2(1), 1-9.

Zerbock, O. (2003). "Urban solid waste management: Waste reduction in developing nations," School of Forest Resources and Environmental Science, Michigan Technological University, Michigan.

Zhang, H., Zhao, Y., and Qi, J. (2007). "Study on use of MSWI fly ash in ceramic tile," Journal of Hazardous Materials 141(1), 106-114. DOI: 10.1016/j.jhazmat.2006.06.100

Zhang, H., Zhao, Y., and Qi, J. (2011). "Utilization of municipal solid waste incineration (MSWI) fly ash in ceramic brick: Product characterization and environmental toxicity," Waste Management 31(2), 331-341. DOI: 10.1016/j.wasman.2010.10.017

Zhang, P., Zeng, G., Zhang, G., Li, Y., Zhang, B., and Fan, M. (2008). “Anaerobic codigestion of biosolids and organic fraction of municipal solid waste by sequencing batch process," Fuel Processing Technology 89, 485-489.

Zhang, R., Luo, Y., and Yin, R. (2018). "Experimental study on dioxin formation in an MSW gasification-combustion process: An attempt for the simultaneous control of dioxins and nitrogen oxides," Waste Management 82, 292-301. DOI:

10.1016/j.wasman.2018.10.042

Zhang, Z., and Ma, J. (2006). "Efficiency improvement of MSW incinerator with a novel MSW incineration technology integrated with biochemical method," in: International Technology and Innovation Conference (ITIC 2006), Hangzhou, China, 2262-2267. DOI: $10.1049 / \mathrm{cp}: 20061150$. 
Zhang, Z., Zhang, Y., and Wu, D. (2019). "Hybrid model for the prediction of municipal solid waste generation in Hangzhou, China," Waste Management \& Research, SAGE Publications Ltd STM, 37(8), 781-792. DOI: 10.1177/0734242X19855434

Zheng, Y., Zhao, J., Xu, F., and Li, Y. (2014). "Pretreatment of lignocellulosic biomass for enhanced biogas production," Progress in Energy and Combustion Science 42(0), 35-53. DOI: 10.1016/j.pecs.2014.01.001

Zhu, B., Zhang, R., Gikas, P., Rapport, J., Jenkins, B., and Li, X. (2010). “Biogas production from municipal solid wastes using an integrated rotary drum and anaerobic-phased solids digester system," Bioresource Technology 101(16), 63746380.

Zhu, Y., Zhao, Y., Zhao, C., and Gupta, R. (2020). "Physicochemical characterization and heavy metals leaching potential of municipal solid waste incinerated bottom ash (MSWI-BA) when utilized in road construction," Environmental Science and Pollution Research 27(12), 14184-14197. DOI: 10.1007/s11356-020-08007-9

Zuberi, M. J. S., and Ali, S. F. (2015). "Greenhouse effect reduction by recovering energy from waste landfills in Pakistan," Renewable and Sustainable Energy Reviews 44, 117-131. DOI: 10.1016/j.rser.2014.12.028

Article submitted: December 25, 2020; Peer review completed: January 31, 2021;

Revised version received and accepted: February 9, 2021; Published: February 11, 2021.

DOI: 10.15376/biores.16.2.Ram 